
796.

Ana Dili Eğitimi Dergisi
Journal of Mother Tongue Education
www.anadiliegitimi.com
Geliş/Received: 01.04.2020 Kabul/Accepted:09.05.2020
Araştırma Makalesi / Research Paper

\title{
Okur-Tepki Teorisi: Küçük Kara Balık Örneği *
}

\author{
PInar KANIK UYSAL ** \\ Seyit ATEŞ ${ }^{* * *}$
}

Öz

Bu araştırmada edebî bir metinden yola çıkılarak okur tepkilerinin belirlenmesi amaçlanmıştır. Araştırmada durum çalışması desenlerinden bütüncül tek durum deseni yaklaşımı benimsenmiştir. Araştırmanın katılımcıları amaçı örnekleme yöntemi ile belirlenmiş, çalışma grubu 10-11 yaş aralığında toplam 65 öğrenciden oluşturulmuştur. Çalışmada ilk olarak Samed Behrengi'nin “Küçük Kara Balık" adlı kitabı eşliğinde etkileşimli okuma çalışmaları yürütülmüş sonrasında da öğrencilerin bu eser hakkındaki görüşlerine başvurulmuştur. Uygulama sürecinde araştırmacı tarafından tutulan alan notları, öğrenciler tarafından yazılan kompozisyonlar ve okuma çalışmaları tamamlandıktan sonra öğrencilerden elde edilen yazılı görüşler veri toplama aracı olarak kullanılmış, verilerin analiz edilmesinde betimsel analiz ve içerik analizi kullanılmıştır. Kitaba ilişkin okur tepkileri üç farklı şekilde analiz edilmiş; birincisinde Schwartz (1992) tarafından oluşturulan değer sınıflamasına göre hazır tema ve kodlar üzerinden, ikincisinde araştırmacılar tarafından oluşturulan kod ve temalar üzerinden, üçüncüsünde Wollman-Bonilla ve Werchadlo (1995) tarafından geliştirilen kategoriler üzerinden değerlendirme yapılmıştır. Kitaba verilen okur tepkileri analiz edildiğinde "öz yönelim, uyarılım ve iyilikseverlik" temalarına ait olan alt değerlerin sıkık oranının yüksek olduğu, öğrencilerin kitabı içselleştirdikleri ve kendi hayatları ile bağdaştırarak estetik tepkiler verdikleri, "aileye değer verme" özellikle de "anneye bağılık" değerinin ön plana çıktığı tespit edilmiştir. Metnin ötesinde okurun varlığını ve tepkisini görebilmek adına bundan sonraki çalışmalarda farklı yaş grupları ile çalışılarak ahlaki ve bilişsel gelişim dönemlerinin okur tepkileri üzerindeki etkilerinin ortaya çıkarılması önerilmektedir.

Anahtar Kelimeler: Okur tepkisi, çocuk edebiyatı, Samed Behrengi, değer eğitimi, ahlaki gelişim.

\begin{abstract}
This study explored the readers's responses by using a literacy text named "The Little Black Fish" (Kucuk Kara Balik). The present study employed a holistic single case design approach among the case study patterns was adopted. Participants of the study were selected by purposive sampling method and the sample consisted of 65 fifth grade students. In the study, interactive reading activities were conducted with Samed Behrengi's book "The Little Black Fish", then the written opinions of the students regarding the book were consulted. Field notes taken by the researcher during the implementation process, compositions written by the students and written opinions obtained from the students were used as data collection tools during the implementation process, and descriptive analysis and content analysis were used for data analysis. Reader responses to the book were analyzed in three different ways; the first one was based on ready-made themes and
\end{abstract}

Reader-Response Theory: Example of The Little Black Fish

\footnotetext{
${ }^{*}$ Bu makale $\mathrm{VI}^{\text {th }}$ International Eurasian Educational Research (19-22 Haziran 2019) kongresinde sunulan bildirinin genişletilmiş sürümüdür.

** Dr. Öğr. Üyesi, Ordu Üniversitesi, Eğitim Fakültesi, Türkçe ve Sosyal Bilimler Bölümü, Ordu, pinaruysal32@gmail.com, ORCID: orcid.org/0000-0003-1208-9535

*** Doç. Dr., Gazi Üniversitesi, Eğitim Fakültesi, Temel Eğitim Bölümü, Ankara, seyitates@gmail.com, ORCID: orcid.org/0000-0002-4498-0376
} 
codes according to the value classification created by Schwartz (1992) and the second one was based on the codes and themes created by the researchers, the third was based on the categories developed by Wollman-Bonilla and Werchadlo (1995). When the reader responses to the book were analyzed according to Schwartz's (1992) value classification, it was found that the frequency of the subtheme belonging to the themes of "self-direction, stimulation and benevolence" was high, and the values belonging to universalism and to the theme of power were not included in student responses at all. When the themes created based on the data of this study were examined, it was discovered that the students internalized the book and gave aesthetic responses while associating the book with their personal lives, and the value "family valuation", especially "commitment to the mother" was found to be at the forefront. Beyond the text, in order to see the existence and response of the reader, it is recommended to work with different age groups in order to find out the effects of moral and cognitive developmental stages on reader responses.

Keywords: Reader response, children's literature, Samed Behrengi, value education, moral development.

\section{Giriş}

Bu çalışmada bir edebî esere ilişkin okur tepkileri Rosenblatt (1978)'ın okur tepki teorisi temel alınarak incelenmiştir. Rosenblatt (1978) tarafından kavramsallaştırılan okur tepki teorisinde okuma tecrübesinin her okuyucu için benzersiz ve bireysel olduğu belirtilerek okumanın bir süreç olduğu kabul edilir. Bu teori okumanın ve anlamın yalnızca okuyucu tarafından oluşturulmadığını, metinler ve diğer okuyucularla gerçekleşen etkileşimler yoluyla da geliştiğini savunur. Okuyucunun belirli bir konu hakkında bildiklerini metinde sunulan yeni bilgilerle birleştirmesi yoluyla anlamanın gerçekleştiği savunulur (Anderson ve Pearson, 1984; Bransford, Brown ve Cocking, 1999). Herhangi bir edebiyat eserinin okunması, okuyucunun aklını ve duygularını içeren bireysel ve benzersiz bir oluşumdur (Rosenblatt, 1983). Okur-tepki teorisi, okuyucunun metinden anlam oluşturmadaki rolüne dair yeni bir anlayış getirmiş, bir metnin her okuyucu üzerinde farklı çağrışımlar uyandırdığını belirtmiştir (Cox ve Many, 1992). Okuyucunun aynı metni sonraki okumalarında farklı yorumlaması da mümkündür. Çünkü metin aynı kalsa da okuyucunun deneyimleri, okuma ortamı ve hayata bakış açısı gibi birçok birleşende değişim meydana gelme olasılığı söz konusudur. Bu nedenle de her okuma bir öncekinden farklı çağrışımlar doğurur. Yazarın ve okuyucunun yaşam deneyimleri ile dünya görüşleri bir metin üzerinde buluşur ancak her okuyucu aynı yazardan farklı kazanımlar elde edebilir. Okuyucunun metindeki anlam arayışı, kendi dünyasındaki olası değişkenler kadar geniştir. Bu, okuyucuların edebî bir eserden tek bir ana fikir çıkarması gerektiği görüşüne bir alternatif sunar. Bunun yerine her okuyucunun metni kendi deneyimleri ve kendi dünyası ışı̆̆ında değerlendirerek bir anlam kurabileceğini kabul eder. Bu bakış açısı da derslerde öğrencilere her metinde bir ana fikir ya da her şiirde bir ana duygu vardır düşüncesinin dikte edilmesinin ötesine geçilerek öğrencilerin bireysel yorumlarına önem verilmesinin gerekliliğini ortaya koyar. Her öğrencinin birbirinden farklı yorumlarına değer verilmelidir. Çünkü yorumlama, anlama işleminin vazgeçilmez bir parçasıdır (Moreillon, 2007). Bir metnin metinsellik ölçütlerini taşıması, bu da bir ana fikir etrafında yoğunlaşmasını gerektirmekle birlikte öğrencilere kendi yaşam deneyimi ve bireysel yorumlarından hareketle bu ana fikre ulaşması için fırsat verilmelidir. Öğretmenin zihninde var olan tek bir doğru cümleyi bulamayan öğrencinin cevabı yanlış ve yok sayılmayarak metin üzerinde fikir alışverişine dayalı bir tartışma ortamı oluşturulup ortak bir yargıya ulaşılmaya çalışılmalıdır.

Rosenblatt (2004) okumayl; metindeki ipuçlarından yararlanma, amaca yönelik seçici dikkat kullanma, okuma süresi boyunca ve okuma sonrasında kendine özgü cevaplar oluşturma, metnin estetik ve bilgi amaçlı okunması arasında amaç değişiminden oluşan karmaşık bir birleşim olarak değerlendirir ve iki farklı okuma türü bulunduğunu ifade eder. Bunlardan biri bilgi edinmeye yönelik okuma, diğeri estetik okumadır. Birincisinde amaç bilgi edinmek iken ikincisinde haz almaktır. Bazen meraktan bazen de okumaktan duyulan keyif okuyucuyu daha fazla okumaya sevk eder. Bilgi amaçlı okuma, olgulara dayanır ve bilişsel, mantıksal ve analitik bir yaklaşım gerektirir. Bunun tersine estetik okuma, daha çok okuyucu deneyimleri ile ilgilidir (Campbell, 2011). Bu bağlamda ders kitaplarındaki bilgi verici metinler okunurken bilgi amaçlı okuma, öyküleyici metinlerde ise estetik okuma türünden yararlanıldığı ifade edilebilir. Öğrenciler öyküleyici metindeki kahramanlar ve olaylar ile kendi 
deneyimleri arasında bir köprü kurmaya, bu deneyimlerden hareketle birtakım çıkarımlarda bulunmaya çalışırlar.

Edebî bir metnin okuyucu tarafından nasıl yorumlandığı, anlamın yapılandırılmasında metnin, yazarın ve okurun ne kadar etkili olduğu soruları başarılı bir okuma eğitimi adına üzerinde durulan önemli konulardan biridir. "Edebi bir metindeki anlamın yapılandırılması ve yorumlanmasında okuyucuya düşen rol nedir?" sorusu kritik önem taşıyan temel değişkenlerden birisi olmasına rağmen alanda yapılan araştırmalarda çoğunlukla yazara ve yazarın ortaya koyduğu anlama, metne ve metnin yazıldığı döneme odaklanıldığı, okurun göz ardı edilerek ona edilgen bir görev yüklendiği görülmektedir. Bu durum çocuk edebiyatı eserleri ve çocukların bu eserlerle olan ilişkisi açısından incelendiğinde de eserlerin çoğunlukla araştırmacıların gözüyle değerlendirildiği (Akkaya, 2014; Arıcı, 2016; Arseven, 2005; Erdal, 2009; Karatay, 2007; Körükçü, Acun Kapkıran ve Aral, 2016; Uzuner Yurt ve Şimşek, 2016) öğrencilerin çıkarımları üzerinde yeterince durulmadığı görülmektedir.

Etkili bir okuma sürecinin gerçekleşmesinin ön koşulu olarak okurun metinle etkileşime girmesi, metni çözümleyip yorumlayarak anlam oluşturabilmesi (Ulusoy, 2016) kabul edilmekle birlikte literatürde okur tepkilerine yönelik az sayıda araştırma olduğu görülmektedir. Öte yandan okumaya bakışın değişmesine ve okur merkezli kuramların ön plana çıkmasına bağlı olarak son yıllarda okur tepkilerine yönelik ilgide kuramsal ve pratik düzeyde bir artış olduğu söylenebilir. Lüleci (2014)'nin "Edebîlik ve edebî metinlerde okuma sürecinin üç bileşeni" isimli çeviri mahiyetindeki ve Baktır (2018)'ın “Metinde anlam: Okur-tepkisi eleştiri kuramı" isimli çalışmaları okur tepkisi üzerine kuramsal bakış açılarını tartışan araştırmalara örnek olarak verilebilir. Uygulama boyutunda ise daha çok resimli çocuk kitaplarına yönelik okur tepkilerinin belirlendiği araştırmalar gözlenmektedir (Aktaş ve Ateş, 2017; Çevik ve Müldür, 2019; Karagöz, 2018; Ulusoy, 2016; Yuran, Ateş ve Çetinkaya, 2017). Sadece Kaya Tosun (2018), dördüncü sınıflarla doktora düzeyinde yaptığı çalışmasında okuma çemberlerine dayalı olarak gerçekleştirdiği okuma etkinliklerinde farklı türde kitaplara yer vermiştir. Araştırmaların neredeyse tamamında katılımcıların okur-merkezli tepkiler verdiklerine, kitaplarla kişisel bağ kurduklarına, kendi yaşamlarıyla özdeşleşen olaylara tepkide bulunduklarına, hikâyedeki olaylara katılma isteği gösterdiklerine yönelik bulgulara ulaşıımıştır. Clarke ve Holwadel (2007), literatürden hareketle eğitimcilerin öğretmenin metne anlam kazandırdığı geleneksel yaklaşımın aksine, öğrencilerin kendi okumalarına sahip olmaları için fırsatlar sağlama gereğinden söz eder. Ancak araştırma literatüründe okur tepkilerine yönelik son yıllarda artan eğilimin benzer şekilde sınıflara yansıdığını söylemek güçtür. Okullarda geleneksel olarak öğretimin ağırlıklı olarak ders kitaplarındaki metinlere bağı olarak yürütülmesi (Ateş, 2011), buna ek olarak çalışma kitaplarındaki düşük düzey etkinliklerin sınırlı bakış açılarıyla ele alınması anlamı sınırlandırmakta (Wolf, 2004) ve öğrenciyi pasif konuma düşürmektedir. Tartışmanın başlatılması ve yönlendirilmesinde, kimin ne kadar konuşacağından nelerin konuşulacağına, nasıl bir açıklama yapılacağına ve hatta hangi cevapların kabul edilebilir olduğuna dair sürecin tek yöneticisinin öğretmenler olduğu yönündeki araştırma bulguları (örn., Ateş, Döğmeci, Güray ve Gürsoy, 2016) metinden anlam kurma çalışmalarının monolojik bir yapıda ve bir okur olarak öğrencilerin tepkilerini dışarıda bırakacak şekilde ilerlediğine işaret etmektedir. Öğrencilerin pasif bir konumda olduğu ve aktarılan bilgiyi istendiğinde yeniden sunmalarının beklendiği bu tür ortamlarda, zaman sorunu nedeniyle her öğrencinin tartışmaya katılamadığı ya da bazı öğrencilerin soru sormaktan ve fikirlerini sınıfın önünde dile getirmekten çekinebileceği gerçeği de dikkate alındığında pek çok öğrencinin sesinin hiç duyulamaması veyahut bir okur olarak tepkisini ortaya koyamaması sık gözlenen bir durumdur (Ateş vd., 2016). Oysaki yaşam gerçeğine uygun yaşantılar sunan kitaplar karşısında çıkarsama sorumluluğu çocuğun kendisine verilmelidir (Maltepe, 2009). Bütün bu nedenlerden ötürü bu çalışmada okur merkeze alınarak bir çocuk edebiyatı eserini çocukların bakış açısıyla değerlendirmek hedeflenmiş, 10-11 yaş aralığındaki öğrencilerin "Küçük Kara Balık" adlı eserle ilgili okur tepkileri ortaya çıkarılmaya çalışılmıştır. Araştırmada kullanılacak çocuk edebiyatı eseri ile ilgili karar verilirken ilgili literatür taranmış ve hakkında birçok araştırma (Akçay ve Baş, 2015; Alamdar, 2017; Ateş, Yıldııım ve Çetinkaya, 2019; Belet Boyacı, Güner ve Babadağ, 2017; Çolaker, 2009; Ertan, 2011; Gözütok, 2008) yapılarak değerler eğitiminde kullanılabileceği (Akçay ve Baş, 2015; Belet Boyacı vd., 2017; Erkan ve Aykaç, 2014) ifade edilen "Küçük Kara Balık" adlı eser seçilmiştir. Ayrıca kitabın çocuklara uygunluğu konusunda karar 
verici konumda olan yetişkinlerden bir kısmının bu eserin çocuklara uygun olmadığı yönünde bir anlayışa sahip olmaları (Ateş vd., 2019) bu eserin seçilmesinde etkili olmuştur. Çünkü yetişkinlerin olumsuz olarak yaklaştıkları bir kitaba çocukların nasıl tepkiler vereceği gerçekten merak konusudur. Bu çerçevede araştırmanın amacı doğrultusunda aşağıdaki sorulara cevap aranmıştır:

1. Kitaba verilen öğrenci tepkileri Schwartz (1992) değer sınıflandırmasına göre nasıl bir dağılım göstermektedir?

2. Kitap karakterleri öğrencilere kimi hatırlatmıştır?

3. Öğrenciler kitap karakterlerinden hangisinin yerinde olmak istemiştir?

4. Öğrenciler kitaptan kendilerine nasıl bir mesaj çıkartmıştır?

5. Öğrenciler kitaba nasıl bir son yazmıştır?

6. Öğrenciler kitabı başkalarına tavsiye etmiş midir?

7. Öğrenciler kitabın başkahramanı Küçük Kara Balık'a hangi tavsiyelerde bulunmuştur?

8. Öğrencilerin kitaba verdikleri tepkilerin (metin ve okur merkezli) dağııımı nasııdır?

\section{Araştırmanın Modeli}

\section{Yöntem}

Bu çalışmada nitel araştırma desenlerinden biri olan durum çalışması, durum çalışması desenlerinden de bütüncül tek durum deseni kullanılmıştır. Durum çalışması, sınırlı bir sistemin (durumun) derinlemesine betimlenmesi ve analiz edilmesi (Merriam, 2013), sınırlı bir ya da birkaç sistemden çoklu bilgi kaynakları aracılı̆ıyla detaylı ve derinlemesine bilgi toplanarak keşfedilen temaların raporlanmasıdır (Creswell, 2018). İyi formüle edilmiş bir teorinin teyit edilmesi veya çürütülmesi amacıyla durum çalışması desenlerinden bütüncül tek durum desenini kullanılabilmektedir (Yıldırım ve Şimşek, 2016). Bu araştırmada bütüncül tek durum deseninin tercih edilmesinin iki temel nedeni bulunmaktadır. Bunlardan birincisi araştırmada Rosenblatt (1978) tarafından geliştirilen okurtepki teorisi üzerine çalışılmış olmasıdır. Rosenblatt (1978) bilgi amaçlı ve estetik amaçlı olmak üzere iki tür okuma yapıldığını ifade eder. Buna göre okuyucu bilgi amaçlı okuma yaptığında daha çok metin merkezli, estetik amaçlı okumalar yaptığında ise okuyucu merkezli tepkiler verir. Bu çalışmada da katııımcıların "Küçük Kara Balık" adlı edebî esere ne tür tepkiler verdikleri tespit edilerek Rosenblatt'ın (1978) okur-tepki teorisinde ortaya koymuş olduğu iddialar test edilmiştir. Bu deseninin tercih edilmesinin ikinci nedeni ise katılımcıların söz konusu tepkilerinin Schwartz (1992)'ın değer sınıflamasına göre nasıl bir dağılım gösterdiğinin belirlenmek istenmesidir. Araştırmacılar (Belet vd., 2017) tarafından "Küçük Kara Balık" adlı edebî eserin Schwartz (1992)'ın değer sınıflamasına göre analizi yapılmıştır. Yapılan analizler metin merkezli çıkarımlardır. Bu araştırmada ise okur tepkilerinin Schwartz (1992)'ın değer sınıflamasına göre analizi yapılarak Rosenblatt (1978)'ın belirttiği üzere okuyucuların okuma ortamına deneyimlerini getirip getirmediklerinin, metne katılma isteği gösterip göstermediklerinin daha genel bir ifade ile estetik tepkiler verip vermediklerinin görülmesine katkı sağlamak amaçlanmıştır.

Araştırmanın katııımcıları, veri toplama araçları ve veri analizine ilişkin açıklamalar başıklar halinde aşağıda yer verilmiştir.

\section{Araştırma Grubu}

Bu araştırmada amaçlı örnekleme yöntemi kullanılmıştır. Amaçlı örnekleme; araştırmacının keşfetmek, anlamak, iç görü kazanmak istediği bir örneklem seçimidir (Merriam, 2013). Çalışmada 1011 yaş aralığındaki öğrencilerin okur tepkilerinin alınması hedeflenmiştir. Bu yaş grubunun belirlenmesinde Piaget'nin ahlaki gelişim kuramı temel alınmıştır. Piaget, ahlak gelişimini dışa bağımlı dönem ve özerk dönem olmak üzere iki evrede inceler. Bu kurama göre 10-11 yaşlarından küçük olan çocuklar kuralların yetişkinler tarafından oluşturulduğuna inanırlar ve kuralları sabit, kesin ve değiştirilemez olarak görüler. Ancak 10-11 yaşlarına geldiklerinde ahlaki düşünmeleri değişikliğe uğrar ve kuralların kesin olmadığını, değiştirilebileceğini anlarlar (Aypay, 2018). Okur tepkilerinin alınmasının hedeflendiği "Küçük Kara Balık" adlı eserin öğrenciler tarafından değerlendirilmesinde ve yorumlanmasında ahlaki gelişim döneminin önemli olduğu düşünüldüğü için çalışma bilişsel açıdan 
soyut işlemlerin başladığı, ahlaki açıdan özerkliğe geçiş dönemi olan beşinci sınıf düzeyinde gerçekleştirilmiştir.

Araştırma Ankara merkez ilçesinde yer alan bir okulun beşinci sınıf düzeyindeki öğrencilerinden çalışmaya gönüllü olarak katılan ve ailelerinden izin alınan 65 öğrenci ile 2018-2019 eğitim öğretim döneminde gerçekleştirilmiştir. Öğrencilerin \%52'si kız ( $n=34)$, \%48'i erkektir ( $n=34)$.

\section{Veri Toplama Araçları ve Verilerin Toplanması}

Okur tepkilerini belirlemek amacıyla yürütülen bu çalışmada Samed Behrengi tarafından yazılan "Küçük Kara Balık" adlı edebî eser kullanılmıştır. Illk baskısı 1968 yılında yapılmış olan kitap masal türünde bir çocuk edebiyatı eseridir. Bu eserin Türkiye'de farklı yayınevleri tarafından yapılan çevirileri ve bu eserle ilgili yapılmış akademik çalışmalar (Akçay ve Baş, 2015; Alamdar, 2017; Ateş vd., 2019; Belet Boyacı vd., 2017; Çolaker, 2009; Ertan, 2011; Gözütok, 2008) bulunmaktadır. Doğrudan değer aktarımı yapılmayarak verilmek istenen iletiler dolaylı yoldan aktarıldığı (Erkan ve Aykaç, 2014); anlam oluşturma sorumluluğu çocuğa bırakıldığı için bu eserin nitelikli ve zengin bir çocuk edebiyatı eseri olduğu (Akçay ve Baş, 2015; Belet Boyacı vd., 2017) kabul edilmektedir.

Katılımcıların esere ilişkin tepkilerini alabilmek amacıyla araştırmada takip edilen aşamalar şu şekildedir: Öncelikle araştırmacılardan biri eşliğinde etkileşimli okuma çalışmaları yürütülmüş, bu uygulama ile kitabın olay örgüsü, ana düşüncesi ve kahramanların karakteristik özelliklerinin öğrenciler tarafından tanınması sağlanmıştır. Okuma sürecinde öğrenciler gözlemlenmiş ve sürece dair alan notları tutulmuştur. Okuma sonrası öğrencilerden esere yeni bir son yazmaları istenmiş, yazma ve yazılanları okuma çalışmaları tamamlandıktan sonra okur tepkileri alınmıştır.

Etkileşimli Okuma Süreci ve Alan Notları: Araştırmacının gözlemlerini ve deneyimlerini araştırma süresince yazılı olarak ifade etmesi olarak tanımlanan (Bogdan ve Biklen, 2003) alan notlarında süreci tanımlayan notlar alınmaktadır. Veri toplama sürecinde araştırmacı tarafından etkileşimli okuma sürecine dair alınan notlar ve öğrencilere yazdırılan yazılar alan notları olarak kullanılmıştır. Etkileşimli okuma sonrası katılımcıların esere dair yazdıkları yazılardan bazıları sınıf ortamında okutularak yazılanlar üzerinde öğrencilerin düşünmesi ve tartışması sağlanmıştır. Bu süreçte esas olarak okuyucuların metni anlayıp anlamadıklarının gözlenmesi amaçlanmış, araştırmacı yansız bir yaklaşımla katılımcıları içerik açısından yönlendirmemeye özen göstermiş ve kitaptaki anlatımlar üzerine olumlu veya olumsuz herhangi bir tepkide bulunmamıştır.

Okur Tepkilerinin Alınması: Öğrencilerin esere ilişkin tepkilerini belirlemek amacıyla açık uçlu sorulardan oluşan bir form kullanılmıştır. Form hazırlanırken Hancock (2008) tarafından oluşturulan sorulardan yararlanılmıştır. Hancock (2008) tarafından geliştirilen yönerge soruları ilkokul ve orta dereceli okullara devam eden öğrencilerin edebî metinlere yönelik hem sözel hem de yazılı cevaplarının gelişimini gözlemek için kullanılmaktadır. Bu sorular estetik, deneyimsel, bilişsel ve yorumlayıcı tepkileri almaya yöneliktir. Bu araştırmada katılımcıların estetik tepkilerini belirlemeye yönelik sorular sorulmamıştır. "Bu kitap kendini nasıl hissetmeni sağladı?", "Karakterin yerinde sen olsaydın kendini nasıl hissederdin?" şeklindeki soruların okuyucuyu doğrudan okur merkezli cevaplar vermeye yöneltebileceği düşüncesi bu kararın alınmasında etkili olmuştur. Nitekim okur tepkilerini belirlemeye yönelik ulaşılabilen çalışmalarda (Karagöz, 2018; Ulusoy, 2016; Kaya Tosun, 2018) okur-merkezli cevapların ağırlıkta olması ve veri toplama sürecinde estetik tepkileri belirlemeye yönelik soruların sorulmuş olması bu düşünceyi destekler niteliktedir. Bu düşünceden hareketle katılımcıların esere ilişkin tepkilerini belirlemek amacıyla deneyimsel (örn., kitap karakterlerinin kendilerine kimi, neyi nasıl hatırlattığına), bilişsel (örn, kitap karakterlerinden hangisinin yerinde olmak istediklerine veya karaktere ne gibi tavsiyelerde bulunmak istediklerine) ve yorumlayıcı (örn, kitaptan kendilerine nasıl bir mesaj çıkarttıklarına) türde sorular sorulmuştur.

Veri toplama araçlarının geçerliği için Türkçe eğitimi alanında iki, program geliştirme alanında ve sınıf eğitimi alanında birer olmak üzere dört uzmanın görüşüne başvurulmuştur. Alan uzmanlarından biri benzer şekilde okur tepkilerini almaya yönelik çalışmalar yürütmüş olup, estetik tepki almaya yönelik soruların çıkarılmasının uygun olacağı yönünde görüş belirtmiştir. Öte yandan okur tepkilerini almaya yönelik kullanılan formun literatürde ulaşılabilen pek çok çalışmada (Çevik ve Müldür, 2019; Karagöz, 2018; Ulusoy, 2016; Yekeler ve Ulusoy, 2017) kullanıldığı ve etkili bir araç olarak 
nitelendirildiği görülmektedir. Ayrıca estetik tepkileri belirlemeye yönelik sorular çıkarılarak oluşturulan formun uzman görüşleri sonrasında üç öğrenci ile pilot uygulaması yapılmış; amaca uygunluğu, dil ve anlaşııılığı ile kullanışlılığı test edilmiştir.

\section{Verilerin Analizi}

Araştırmada "toplanan verileri açıklayabilecek kavram ve ilişkilere ulaşmak" (Yıldırım ve Şimşek, 2016, s. 242) ve "verinin temel anlamlarını tanımlamak" (Patton, 2002, s. 453) için içerik analizi kullanılmıştır. Merriam (2013)'a göre bütün nitel veri analizleri içerik analizidir ve durum çalışmasında kullanılan veri toplama araçlarının analizi için uygun bir tekniktir. Araştırma verilerinin çözümlenmesinde betimsel analiz ve içerik analizi tekniği kullanılmış, betimsel istatistikler "yüzde" olarak verilmiştir. Yüzdelik ifadeler katılımcıların araştırma verisi içinde saptanan tema veya kategorilere ne oranda katıldıklarını göstermek (Tutty, Rothery ve Grinnell, 1996) amacıyla kullanılmıştır. Katılımcılardan elde edilen okur tepkilerine ilişkin verilerin derinlemesine analiz edilmesi ve önceden belirgin olmayan tema ve kodların ortaya çıkarılması için içerik analizi; Schwartz (1992) değer sınıflaması tablosundaki hazır tema ve kodların özetlenip yorumlanması ve katılımcıların yazılı cevaplarının okur veya metin merkezli olup olmadığını belirlenmesi için betimsel analiz kullanılmıştır. Veri analiz sürecinin daha açık ve sistematik hale getirilmesi (Creswell, 2017) amacıyla MAXQDA ${ }^{\odot}$ adlı nitel veri analizi programından yararlanılmıştır.

Analizlerin yapılmasında şu aşamalar izlenmiştir:

i) Birinci aşamada Schwartz (1992) değer sınıflaması tablosundaki tema ve kodlar kullanılarak analiz yapılmıştır. Schwartz (1992) tarafından yapılan değer sınıflandırması, evrensel 10 değer tipi ve bunların içerdiği 56 alt değeri kapsayan, Türkiye'nin de bulunduğu 40'tan fazla ülkede uygulanarak oluşturulan bir değer sınıflamasıdır (Belet Boyacı vd. 2017). Veriler iki araştırmacı tarafından iki kez genel hatlarıyla üç kez de detaylı bir şeklide okunarak oluşabilecek kodlarla ilgili kısa notlar alınmıştır. Alınan notların sonucunda Schwartz (1992) değer sınıflamasında yer almamasına rağmen bu çalışmanın veri setinden çıkan bazı değerlerin sınıflamaya eklenmesine karar verilmiştir. Kodlamalar sırasında bazı kavramlar değer sınıflaması listesine şu şekilde alınmıştır: "Kendini beğenmiş, kibirli" ifadeleri geleneksellik teması "alçak gönüllü" değer tipi içerisinde; "macera, heyecan" ifadeleri uyarılım teması "heyecanlı bir yaşantı sahibi olmak" değer tipi içerisinde; "amacından vazgeçmemek, pes etmemek, amacına ulaşmak için çabalamak" kavramları özyönelim teması "kararlı olmak" değer tipi içerisinde; "akıllı, bilgili" kavramları başarı teması içerisinde; "fedakârlık" kavramı iyilikseverlik teması içerisinde; "mutluluk" kavramı hazcılık teması içerisinde ele alınmıştır.

ii) İkinci aşamada okur-tepki soruları tema olarak belirlenmiş, kodlamaların bu temalar altında yapılması planlanmıştır. a) okur-tepki sorularından oluşturulan temalar ve bu temalar altında oluşturulan kodlar üzerinde tartışılarak bazı kodların birleştirilmesine bazıları için de yeni bir tema oluşturulmasına karar verilmiştir. b) nitel verilerin yüzde verilerek sayısallaştırılması; güvenirliğin artıııması, yanlılığın azaltılması, yorumların daha adil bir şeklide yapılması ve ortaya çıkan tema ve kategoriler arasında karşılaştırma yapılabilmesine olanak sağladığı (Yıldırım ve Şimşek, 2016) için analiz sonucunda ortaya çıkan kategorilere yönelik yüzdeler verilerek bu veriler yorumlanmıştır.

iii) Üçüncü aşamada katılımcıların yazııı cevaplarının okur veya metin merkezli olup olmadığını belirlemek için Wollman-Bonilla ve Werchadlo (1995, s. 564-565) tarafından geliştirilen ve Ulusoy (2016) tarafından "ana fikir" alt teması eklenen aşağıdaki kategoriler kullanılmış, bu kategorilere uyan cevapların frekans ve yüzdeleri hesaplanmıştır.

Metin merkezli cevaplar

1. Hikâyeyi yeniden anlatma

2. Karakterleri anlama

3. Soru sorma

4. Tahmin etme

5. Ana fikir
Okur merkezli cevaplar

1. Kişisel tepki (düşünceler ve hisler)

2. Hikâye ile deneyimleri arasında bağlantı kurma

3. Hikâyedeki olaylara katılma isteği 


\section{Geçerlik ve Güvenirlik}

Çalışmanın geçerliği ve güvenirliğini sağlamak için veri toplama sürecinde birden fazla veri türü kullanılmış, katılımcıların belirlenme ölçütleri açıklanmış, veri toplama ve analiz süreci anlatılmış, toplanan verilerden elde edilen sonuçlar veri toplama sürecinde kendisinden veri toplanan öğrencilerin Türkçe öğretmenine okutularak oluşturulan rapor hakkında görüşleri alınmıştır. Veri toplama süreci iki aşamalı (kitabın etkileşimli okunması ve tüm bu süreç içerisinde ve süreç tamamlandıktan sonra gözlem ve görüşmelerin yapılması) olduğu için araştırmacı öğrencilerle daha uzun süre etkileşim içinde bulunma ve onları daha iyi gözlemleme şansı elde etmiştir. İç geçerliğin sağlanabilmesi için çalışmanın sonuçlarına nasıl ulaşıldığı ve çıkarımların nasıl elde edildiğine kanıt göstermek amacıyla öğrenci tepkilerinden örnek cümleler sunulmuştur. Veri analiz sürecinin daha açık ve sistematik hale getirilmesi amacıyla (Creswell, 2017) MAXQDAC adlı nitel veri analizi programından yararlanılmıştır. İçerik analizi sürecinde kodlamanın geçerlik ve güvenirliğini sağlamak için veri seti farklı zaman dilimlerinde (birinci kodlama ile ikinci kodlama arasında altı ay, ikinci kodlama ile üçüncü kodlama arasında üç aylık bir zaman dilimi bulunmaktadır) üç kez kodlanmıştır. Veri seti, analiz programına yüklenmeden önce iki kez genel anlamda üç kez de üzerinde notlar alınarak detaylı bir şekilde iki araştırmacı tarafından incelenmiş, oluşabilecek tema ve kodlar üzerinde tartışıımıştır. Birinci aşamada oluşturulan tema ve bunlar üzerine yapılan kodlamalar bir program geliştirme uzmanı ve bir Türkçe eğitimi alan uzmanı olmak üzere iki uzmana gösterilmiş, uzmanlardan alınan görüşler doğrultusunda kodlamalar tekrar gözden geçirilerek bazı kodlar aynı tema altında birleştirilmiştir. íkinci kez yapılan analizde oluşturulan tema ve kodlar tekrar gözden geçirilmiş ve üzerinde yapılan birkaç değişiklikten sonra iki araştırmacı arasında görüş birliğine varılarak kodlama sistemine son hali verilmiştir. Veri seti son kez bu tema ve kodlar üzerinden analiz edilerek araştırma bulgularına ulaşılmıştır.

\section{Bulgular}

Araştırma sorularına yanıt aramaya yönelik bulgular sekiz alt başlık halinde aşă̆ıda sunulmuştur.

\section{Okur-Tepkilerinin Schwartz (1992) Değer Sınıflandırmasındaki Dağııımına iliş̧kin Bulgular}

Okur-tepkilerinin Schwartz (1992) değer sınıflandırmasına göre nasıl bir dağılım gösterdiğine ilişkin bilgilere Şekil 1'de yer verilmiştir.

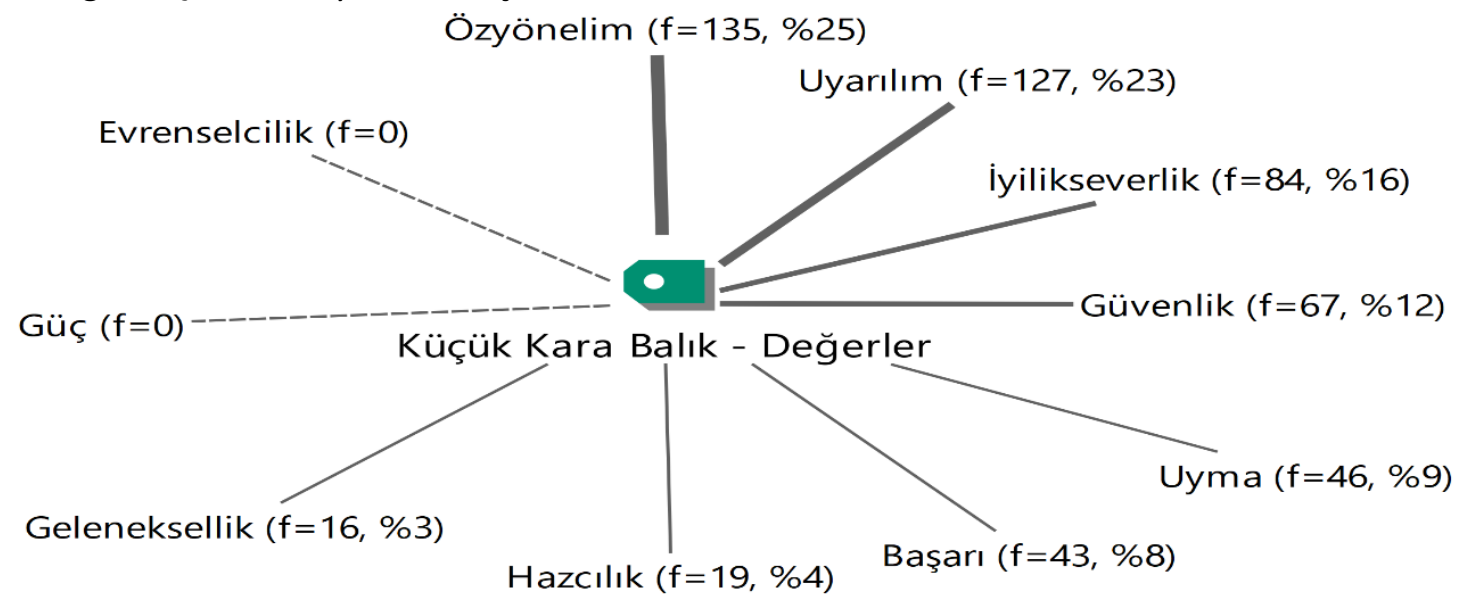

Şekil 1. Okur-Tepkilerinin Schwartz (1992) Değer Sınıflandırmasına Göre Dağılımı

Okur tepkileri Schwartz (1992) değer sınıflandırmasına göre incelediğinde değer temalarının ortaya konma sıklı̆̆ı açısından özyönelim teması $\% 25$, uyarılım teması $\% 23$, iyilikseverlik \%16, güvenlik $\% 12$, uyma \%9, başarı \%8, hazcılık \%4, geleneksellik \%3 olarak tespit edilmiştir. Özyönelim (\%25) teması içerisinde "meraklı olmak", "kendi amaçlarını seçebilmek" ve "kararlı olmak (hayallerinden vazgeçmemek) en sık geçen alt değerler olarak tespit edilmiştir. Bu alt değerlere kaynaklık eden ifadelerden bazıları şu şekildedir: "Küçük Kara Balık gibi cesur ve meraklı olun (Ö6)." "Hayallerinizin 
arkasında durun, meraklı olun (Ö23)." "Kendi kararlarınızı kendiniz verin, hayallerinizi gerçekleştirmek için çabalayın (Ö40)." "Arkadaşlar, eğer bir şeye göz koyduysanız onu yapmaya gayret edin lütfen, sabırlı olursanız, gayret ederseniz hayallerinize ulaşabilirsiniz (Ö32).".

Uyarılım (\%23) teması içerisinde "cesur olmak", "değişken bir hayat yaşamak" ve "heyecanlı bir yaşantı sahibi olmak" en sık geçen alt değerler olarak tespit edilmiştir. Bu alt değerlere kaynaklık eden ifadelerden bazıları şu şekildedir: "Sakın ola ki korkmayın, arkadaşlarınızı satmayın, zamanı geldiğinde zeki, bilge ve cesur olun. Kendi yolunuzu kendiniz çizin, unutmayın kimse sizin hayatınıza karışamaz. (Ö16)." "Korkularını bir yere bırakıp cesaretini göster. Gez, gör, soru sor ama asla hiçbir şeyden korkma (Ö25).” "Maceranın peşini bırakmayın (Ö12)." “Her zaman için yeni yerler keşfetmeliyiz. Hep aynı yerde kalmamalıyız. Ama evden kaçın, ayrılın gidin anlamında demiyorum. Mesela yaşınıza göre uygun yerlere gidin demek istiyorum (Ö10)." "Aynı yerlerde kalmamalıyız, keşfetmediğimiz yerleri keşfetmeliyiz (Ö29).".

İyilikseverlik (\%16) teması içerisinde "yardımsever olmak", "gerçek arkadaşlık" ve "dürüst olmak" alt değerleri okur tepkilerinde en çok yer alan alt değerler olarak şu şekilde geçmektedir: "Yardımsever, korkusuz, cesaretli ve yeniliklere açık olmalıyız (Ö34)." "Arkadaşlar, siz siz olun başkalarının sözüyle size destek çıkan sizi seven kişileri asla ve asla yolda bırakmayın. (Ö60)." Araştırma esnasında yapılan gözlemlerde "Ö60" kodlu öğrencinin sınıf arkadaşlarıyla yaşadığı sorunlar olduğu, sınıfta bir gruplaşma olduğu ve bu öğrencinin en yakın arkadaşı tarafından hayal kırıklı̆ına uğratıldığı görülmüştür. Bu nedenle de bu öğrenci kitaptaki küçük balıkların Küçük Kara Balık'ı yarı yolda bırakmasını kendi özel yaşamı ile bağdaştırmış ve tepkisini bu yönde vermiştir.

Güvenlik (\%12) teması içerisinde "bağlılık (aileye bağlılık)" ve "iş birliği" alt değerleri okur tepkilerinde en çok yer alan alt değerler olarak şu şekilde geçmektedir: "Annesinin yanından ayrılmamalıydı (Ö36)." "Annesini bırakmamalıydı (Ö40)." "Bir daha sakın annenin yanından ayrılma (Ö18)." "Küçük Kara Balık, anneni üzme çünkü sen onun tek değerlisisin (Ö15)." "Ailenizi, birbirinizi bırakmayın. Ölüm bile olsa bırakmayın (Ö20).".

Uyma (\%9) teması içerisinde "ana babaya ve yaşlılara değer vermek" ve "itaatkâr olmak" alt değerleri okur tepkilerinde en çok yer alan alt değerler olarak şu şekilde geçmektedir: "Ebeveynlerinizin sözünü dinleyin, başınıza kötü şeyler gelebilir (Ö50)." "Annenin sözünü dinlemelisin (Ö34)." "Bir daha böyle yapmamalı, annesinin sözünü dinlemeli (Ö43)." "Keşke ailesinin sözlerini, nasihatlerini dinleseydi. Ama o yanlış yaptı ve öldü. Eden bulur (013)." Araştırma sürecinde alınan notlarda "Ö13" kodlu öğrencinin aile yaşamında anne otoritesinin baskın olduğu ve bu kontrol mekanizmasının öğrencinin derslerdeki durumuna da yansıdığı tespit edilmiştir. Annesinin sözünü dinlemeyen bir bireyin ölmeyi hak ettiğini, söz dinlememesinin cezasını çekmesi gerektiğini düşünmektedir. "Ö50" kodlu öğrencinin sınıf kurallarına çok bağlı olduğu ve kurallara uymayan sınıf arkadaşlarından rahatsız olduğu gözlemlenmiştir. Öğrencinin bu özelliği okur tepkisine de yansımış, ailenin sözü dinlenilmediği takdirde arkadaşlarının başına kötü şeyler gelebileceğini ifade etmiştir.

Başarı (\%8) teması içerisinde "zeki olmak" ve "bilgili olmak" alt değerleri okur tepkilerinde en çok yer alan alt değerler olarak şu şekilde geçmiştir: "Teyzem kertenkele gibi bilgili ve yardımseverdir (Ö29)." "Kertenkele bana Onur Saruhan'ı hatırlattı çünkü o da yardımsever ve bilgili bir insandır (Ö40)." "Ö40" kodlu öğrenci ile ilgili alınan notlar incelendiğinde bu öğrencinin sosyal medya merakının olduğu ve bu durumun öğrencinin okur tepkisine de yansıdığı görülmüştür.

Hazcılık (\%4) teması içerisinde "hayattan tat almak" ve "mutluluk" alt değerlerine kaynaklık eden ifadelerden bazıları şu şekildedir: "Bu kitabı okurken kendimi sanki kitabın içinde sandım, ben macerayı seven bir kızım, o heyecanlı anları beni benden aldı ve ayrıca çok mutlu hissettim kendimi (Ö39).".

Geleneksellik (\%3) değer teması içerisinde "alçak gönüllü olmak" ve "hayatın verdiklerini kabullenmek" alt değerleri okur tepkilerinde şu şekilde geçmektedir: "Kendinizi kimseden büyük görmeyin (Ö32)." "Arkadaşlar, hiçbirimiz kendimizi büyük görmemeliyiz. Diğerlerimizi küçük düşürmemeliyiz (Ö6)." "Asla ve asla kendimizi büyük görmemeliyiz (Ö11).”.

Evrenselcilik ve güç temalarına ait alt değerler öğrenci tepkilerinde bulunamamıştır. Okur tepkilerinde "otorite sahibi" olmak değerinin ötesinde "önder olmak" ve "iş birliği" içerisinde olmak değerlerinin yer aldığı görülmüştür. 


\section{Kitap Kahramanlarının Kimi Hatırlattığına i̇lişkin Bulgular}

Kitap kahramanlarının öğrencilere kimleri hatırlattığına ilişkin bilgiler Şekil 2'de gösterilmiştir.

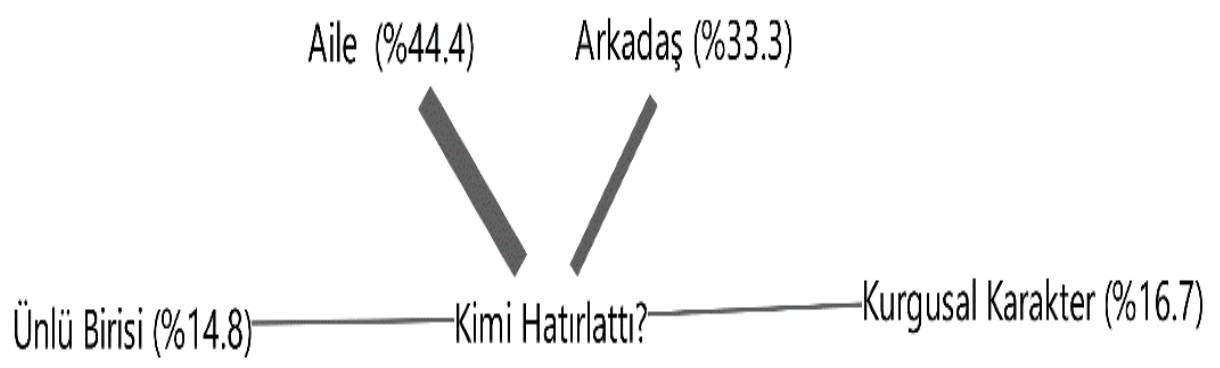

Şekil 2. Kitap kahramanlarının Kimi Hatırlattığına İlişkin Bulgular

Kitap kahramanlarını öğrencilerin \%44.4'ü ailelerinden bir bireye, \%33.3'ü arkadaşına, \%16.7'si kurgusal bir karaktere, $\% 14.8^{\prime} i$ ise ünlü birisine benzetmiştir. Bu karakterleri hangi yönüyle benzettikleri sorusuna alınan cevaplardan oluşan kodlar Şekil 3'te gösterilmiş, okur tepkilerinde geçen ifadeler alıntı cümleler ile örneklendirilmiştir:

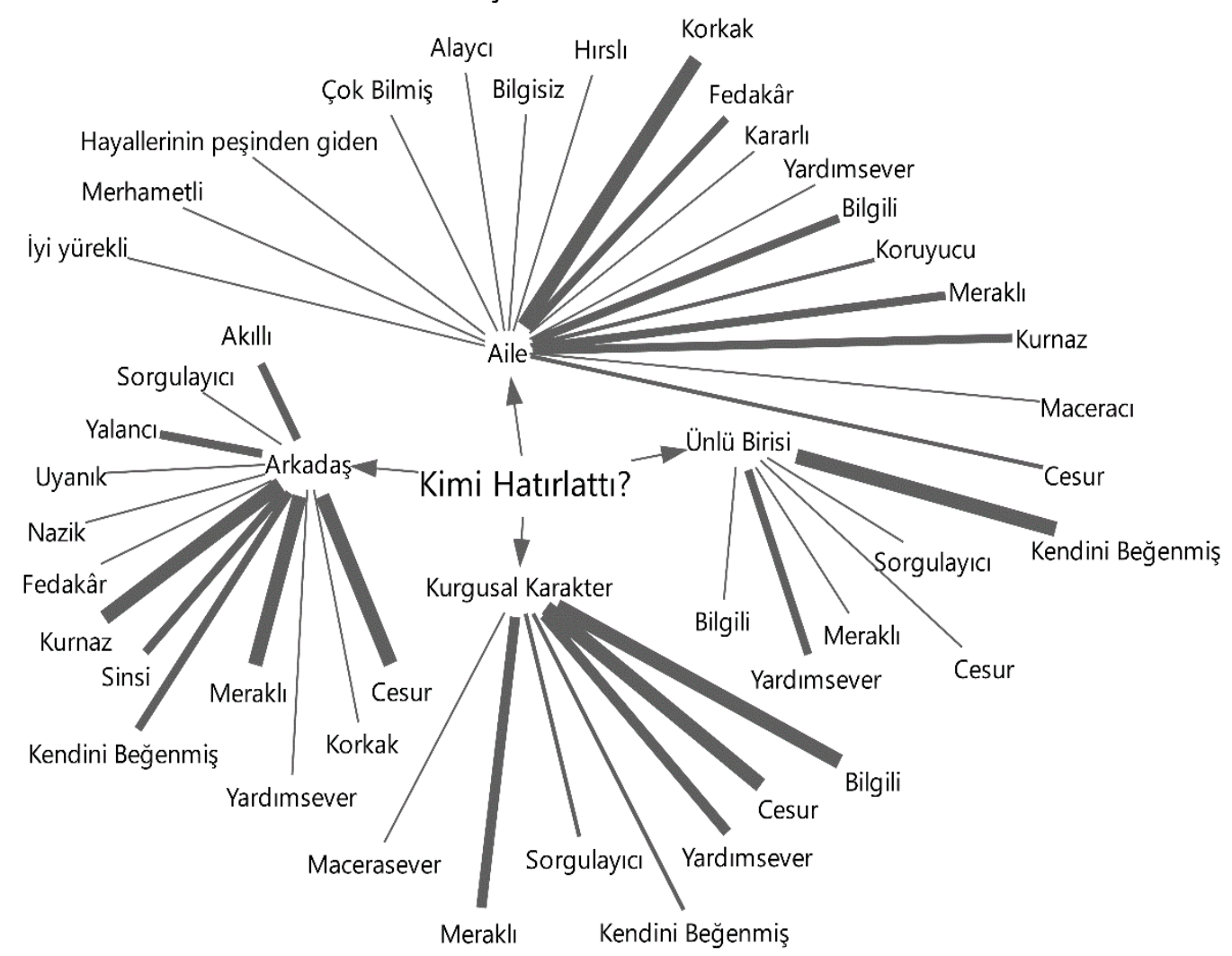

Şekil 3. Kimi Hangi Yönüyle Hatırlattığına Illişkin Bulgular

Şekil 3'te görülen kodlara kaynaklık eden öğrenci ifadelerinden bazıları şu şekildedir: "Annemi Küçük Kara Balık'ın annesine benzettim çünkü o da hiçbir yere götürmez, hep bir yerden gidip döneriz (Ö13)." "Kitabın karakterlerinden biri olan yengeç kurnazlığı ile kuzenime benziyor (Ö53)." "Anne kurbağayı ben anneme benzettim çünkü beni koruyup kolluyor (Ö25)." "Küçük Kara Balık dedem gibi hedeflerinden vazgeçmeyen, kertenkele babam gibi bilgili, anne balık annem gibi korkak (Ö9)." "Arkadaşımı hatırlattı çünkü çok meraklı ve cesur hep her şeyi sorar, her şeyi inceler (Ö61)." "Küçük Kara Balık karakteri bana Balık Nemo'yu hatırlattı. Çünkü ikisi de cesur, bilgili bir karaktere sahip (33)." "Kurbağa yavruları Aleyna Tilki'yi hatırlattı çünkü kendini beğenmiş bir karaktere sahip (Ö44)." Kertenkele Enes Batur'u hatırlattı çünkü lösemili çocuklara yardım edip onlara bağışta bulunuyor (Ö28)." Öğrencilerin verdikleri cevaplar kitap kahramanlarını çoğunlukla aile bireylerinden biri ve 
arkadaşları ile bağdaştırdıklarını göstermektedir. Aile bireylerinin en çok "korkak, fedakâr, bilgili, kurnaz ve meraklı" olma özellikleriyle, arkadaşların ise en çok "cesur, meraklı ve kurnazlık" özellikleriyle kitap kahramanlarına benzetildiği görülmektedir.

\section{Öğrencilerin Kitap Kahramanlarından Hangisinin Yerinde Olmak İstediklerine ilişkin Bulgular}

Öğrencilerin kitap kahramanlarından hangisinin yerinde olmak istediklerine ilişkin bilgiler Şekil 4'te gösterilmiştir.

\section{Küçük Kara Balık (\%70.9)}

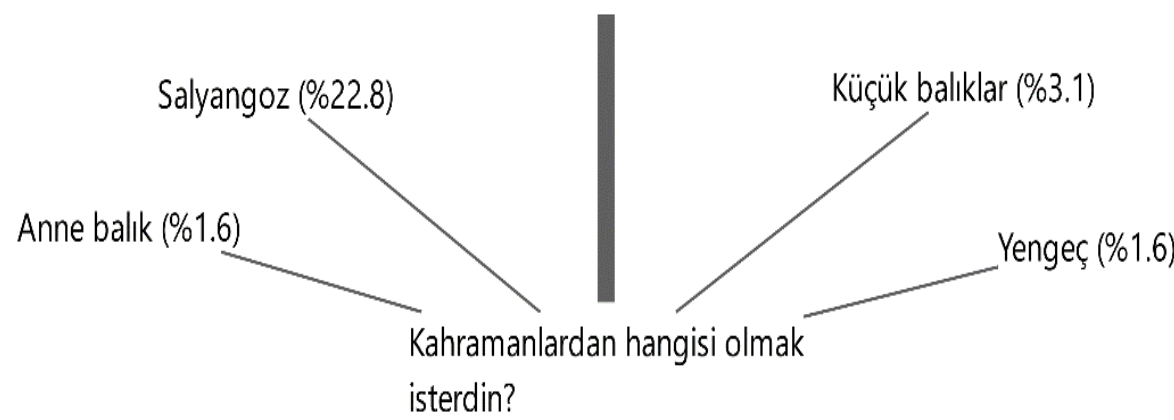

Şekil 4. Öğrencilerin Kitap Kahramanlarından Hangisinin Yerinde Olmak İstediklerine İlişkin Bulgular

Okur tepkileri incelendiğinde öğrencilerin yaklaşık \%71'inin Küçük Kara Balık'ın yerinde olmak istediği görülmektedir. Öğrencilerin bu karakteri seçme sebeplerine ilişkin oluşan kodlar Şekil 5'te gösterilmiştir.

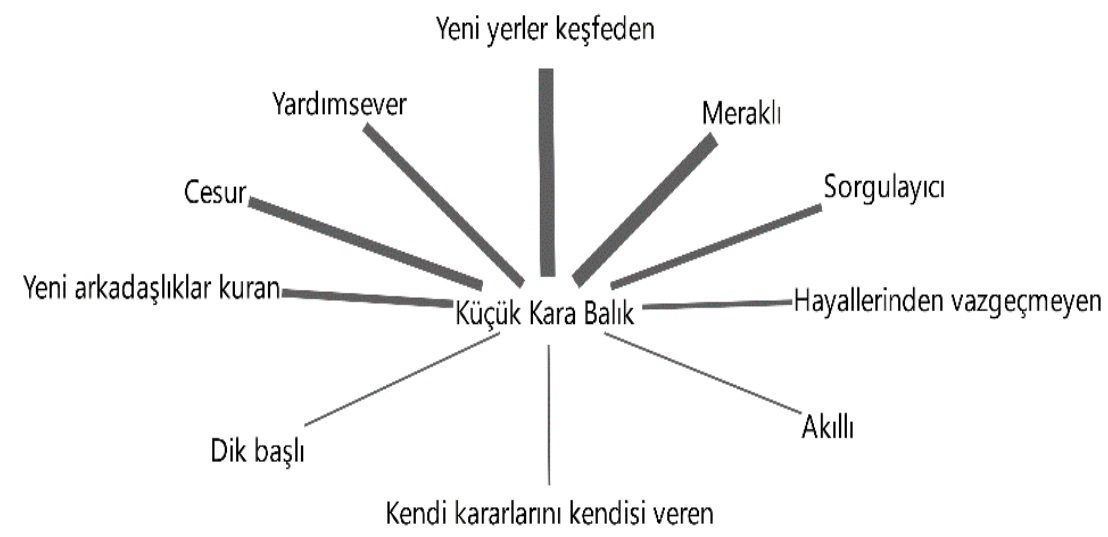

Şekil 5. Niçin Küçük Kara Balık'ın Yerinde Olmak İstediklerine İlişkin Bulgular

Şekil 5'te görülen kodlara kaynaklık eden öğrenci ifadelerinden bazıları şu şekildedir: "Küçük Kara Balık olmak isterdim çünkü onun gibi meraklı ve sorgulayıcı olmak isterdim (Ö11)." "Küçük Kara Balık olmak isterdim çünkü meraklı, sorgulayıcı, cesur olduğu için, kendi kararlarını kendi verdiği için ve yardımsever olduğu için (Ö38)." "Küçük Kara Balık'ı seçerdim. Onun gibi meraklı, hayalinin arkasında duran biri olmak isterdim (Ö17)." "Küçük Kara Balık olup yeni yerler keşfetmek isterdim (Ö21)." Öğrencilerin niçin Küçük Kara Balık'ın yerinde olmak istediklerine ilişkin verdikleri okur tepkilerinde en çok vurgulanan "yeni yerler keşfetmesi", "yardımsever olması", "meraklı ve sorgulayıcı olması" iletileri olmuştur. 


\section{Öğrencilerin Kitaptan Kendilerine Nasıl Bir Ders Çıkarttıklarına İlişkin Bulgular}

Öğrencilerin kitaptan kendilerine nasıl bir ders çıkarttıklarına ilişkin bilgiler Şekil 6'da gösterilmiş ve oluşan kodlar öğrenci tepkilerinden alınan örnek cümleler ile desteklenmiştir.

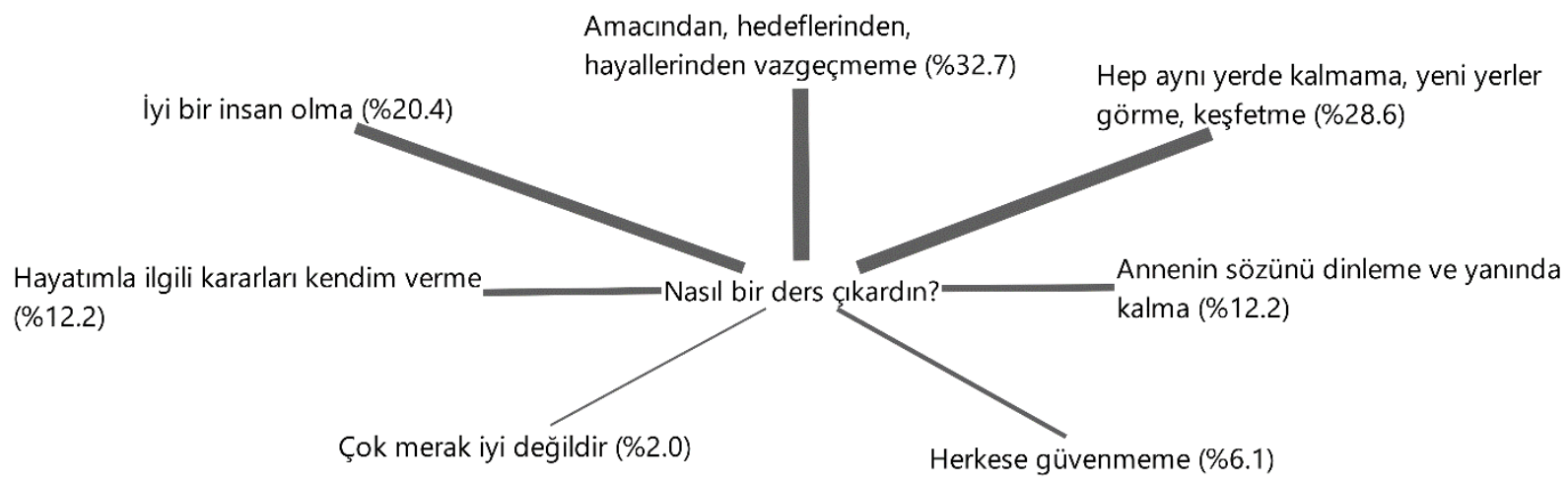

Şekil 6. Kitaptan Nasıl Bir Ders Çıkarıldığına İlişkin Bulgular

Şekil 6 incelediğinde öğrencilerin \%32'si amaçlarından, hedeflerinden ve hayallerinden vazgeçmemesi gerektiğini, \%28'i hep aynı yerde kalmayarak yeni yerler keşfetmesi gerektiğini, \%20'si iyi bir insan olması gerektiğini, \%12'si annesinin sözünü dinleyerek onun yanında kalması gerektiğini, $\% 12$ 'si hayatıyla ilgili kararları kendisi vermesi gerektiğini, \%6'sı herkese güvenmemesi gerektiğini kendisine ders olarak çıkartmıştır. Oluşan bu kodlara kaynaklık eden öğrenci ifadelerinden bazıları şu şekildedir: "Bu kitaptan şöyle bir ders çıkardım. Her zaman yeni yerler görmeliyiz, yeni diller öğrenmeliyiz (Ö37)." "Hep aynı yerde olmamalıyız, yeni yerler keşfetmeliyiz. Örneğin biz hep okuldan eve evden okula gidip gelseydik hayat sıkıcı olurdu yeni yerler göremezdik (Ö10)." "Bir amaca ulaşmak için yola çıkanlar her türlü zorluklara rağmen eninde sonunda hedeflerine ulaşırlar (Ö24)." "Bir amaca ulaşmak için yola çıktıysan devam et korkma eğer sabredersen sonu güzel olur (Ö32)." "Ne olursa olsun hayallerinin peşinden gitmeyi, önüne birçok engel çıksa da aşmamız gerektiği dersini çıkardım (Ö41)." "Kendi kararlarımızı kendimiz vermeliyiz, bir hedefimiz olmalı ve bu hedefi gerçekleştirmeye çalışmalıyız (Ö29)." “Ö29" kodlu öğrencinin akademik anlamdaki başarısı ve ders içindeki örnek davranışları araştırmacı notlarına yansımış, bu öğrencinin ileride başarılı bir birey olacağına dair notlar tutulmuştur. Bu öğrenciden elde edilen okur tepkisi bu öğrencinin bir hedef doğrultusunda disiplinli bir şekilde çalışacağına ve hayatta kendi kararlarını kendisi alabilen bir birey olabileceğine ilişkin beklentileri desteklemiştir.

\section{Kitap için Yazılan Sonuç Bölümüne ilişkin Bulgular}

Öğrencilerin kitap için yazdıkları sonuç bölümüne ilişkin bilgiler Şekil 7'de gösterilmiştir.

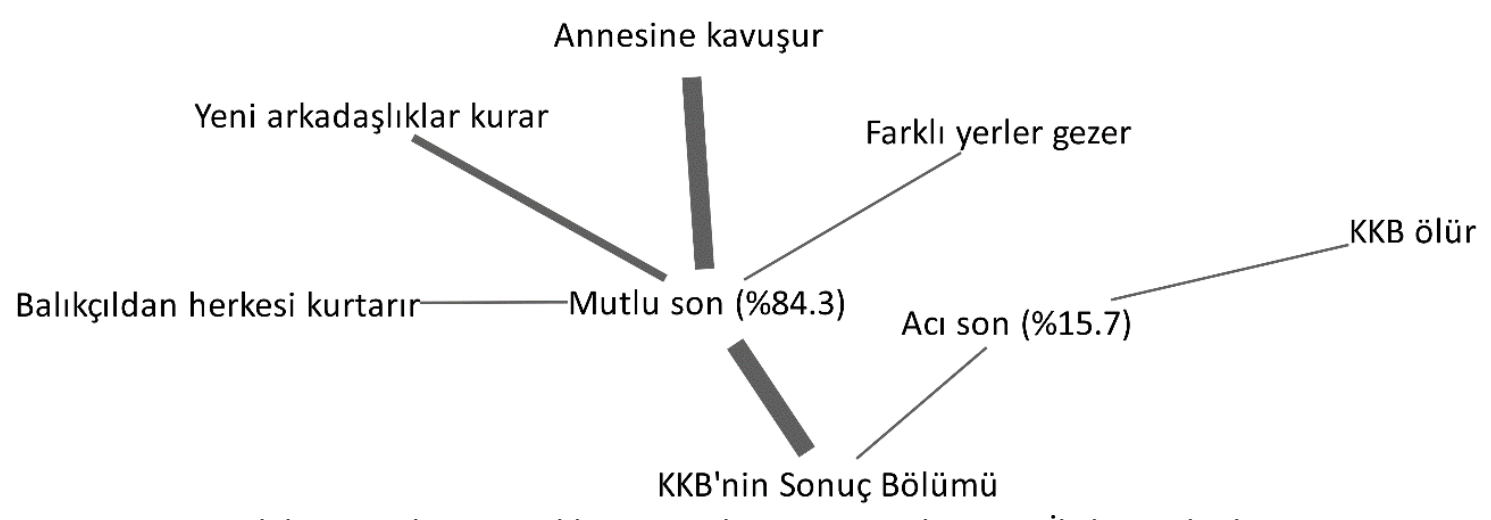

Şekil 7. Küçük Kara Balık için Yazılan Sonuç Bölümüne Illişkin Bulgular 
Şekil 7 incelendiğinde öğrencilerin \%84.4'ünün kitaba mutlu bir son yazarak Küçük Kara Balık'ın kurtulduğunu ve annesine kavuştuğunu ifade ettikleri, \%15.7'si ise acı bir son yazarak Küçük Kara Balık'ın öldüğünü ya da döndüğünde annesini bulamadığını belirttikleri görülmüştür. Bu kodlara kaynaklık eden öğrenci ifadelerinden bazıları şu şekildedir: "Kitabın sonunda Küçük Kara Balık'ın annesi ile birlikte mutlu bir şekilde yaşayacağını düşünüyorum (Ö62)." "Küçük Kara Balık annesine kavuşmuştur ve artık her yere annesiyle birlikte gider (Ö55)."” Bence, Küçük Kara Balık'ı yutan Balıkçı'ın midesine köpek balığı çarpar ve Balıkçıl'ın midesi patlar. Küçük Kara Balık kurtulur ve sonra evine geri döner. Annesine yaşadığı her şeyi anlatır. Sonra annesi ona: 'Seninle gurur duyuyorum.' der (Ö64)." "Küçük Kara Balık Balıkçıl’ın midesinde nefes alamayıp ölür (Ö47)." "Öleceğini düşünüyorum çünkü balıkçıın midesinde kaldığında balıkçılın onu çiğneyerek yutacağını düşünüyorum (Ö59)." Öğrencilerin büyük çoğunluğunun Küçük Kara Balık'ın yaşayacağı ve annesine kavuşacağı yönünde bir son yazması, mutlu sonla biten bir masal geleneğinin içinden geliyor olmalarından kaynaklanıyor olabilir. Masalların çoğunda bitiş tekerlemesi olarak gökten üç elma düşer, herkes payını alır ve mutlu sona ulaşılır. Okur tepkileri bu geleneğin bir yansıması olarak değerlendirilebilir.

\section{Küçük Kara Balık'a Verilen Tavsiyelere İlişkin Bulgular}

Öğrencilerin kitabın başkahramanı Küçük Kara Balık’a verdikleri tavsiyelere ilişkin bilgiler Şekil $8^{\prime}$ de gösterilmiştir.

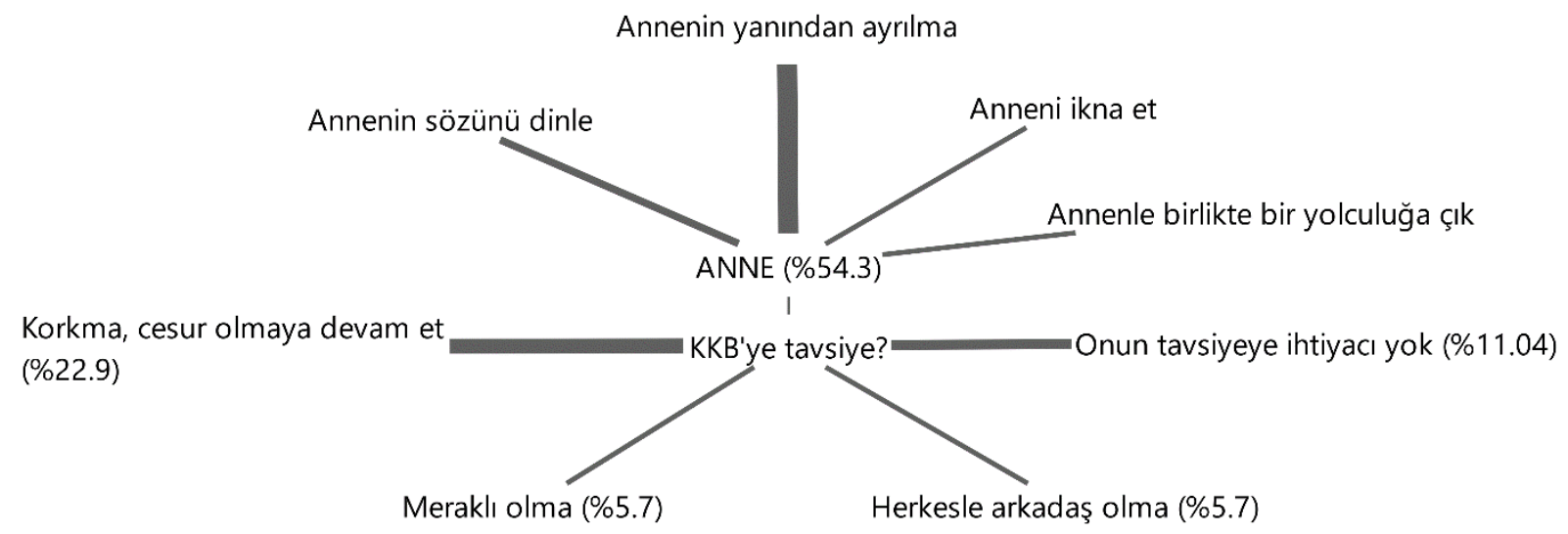

Şekil 8. Küçük Kara Balık’a Verilen Tavsiyelere İlişkin Bulgular

Şekil 8 incelendiğinde öğrencilerin \%54'ünün Küçük Kara Balık’a annesi ile ilgili bir tavsiyede bulunduğu görülmektedir. \%22.9'u Küçük Kara Balık'ın korkmayarak cesur olmaya devam etmesi gerektiğini, \%5.7'si meraklı olmaması, \%5.7'si herkesle arkadaş olmaması gerektiğini ifade etmiştir. \%11.4'ü ise Küçük Kara Balık'ın tavsiyeye ihtiyacı yok, onun yaptığı her şey doğruydu şeklinde cevaplar vermiştir. Oluşan kodlara kaynaklık eden öğrenci ifadelerinden bazıları şu şekildedir: "Evinden uzaklaşmamasını önerirdim (Ö10)." "Küçük Kara Balık'a bir daha sakın annenin yanından ayrılma demek isterdim (Ö13)." "Küçük Kara Balık'a vereceğim tek tavsiye bu kadar çok meraklı olmamasıdır. Meraklı olmak ilerleyen zamanlarda başımıza bela açabilir (Ö41)." "Ona tavsiye vermeme gerek yok çünkü o benden de zeki (Ö22)." "Yoluna devam etmeli, bilmeli ki yaptığı şey çok cesurca. Bu şekilde olmalı ve balıkları peşine takarak örnek bir balık olmalıdır (Ö3)."

Öğrencilerin okur tepkilerinde en dikkat çeken unsur, "anne" üzerinde bu kadar durulması, Küçük Kara Balık'a annesini üzmemesi konusunda tavsiyeler verilmiş olmasıdır. Öğrenciler Küçük Kara Balık'ın cesurluğunu, sorgulayıcılığını, merakını, yeni yerler keşfetme tutkusunu, hayallerinin peşinden gitmesi ve bu uğurda gösterdiği azmi ve sabrı takdir etmekte ancak tüm bunları yaparken annesini üzmesini ve ondan ayrılmasını onaylamamaktadır. Bu nedenle de ona annesini ikna ederek onunla birlikte yeni yerler keşfetmesini önermektedirler. 


\section{Kitabın Başkasına Önerilmesine illişkin Bulgular}

Öğrencilerin kitabı başkalarına önerip önermediklerine ilişkin bilgiler Şekil 9'da gösterilmiştir.

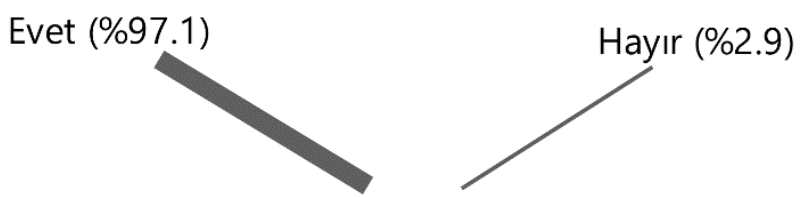

KKB'yi tavsiye eder misin?

Şekil 9. Kitabın Başkalarına Önerilmesine ilişkin Bulgular

Şekil 9 incelendiğinde öğrencilerin \%97'sinin kitabı başkalarına da tavsiye ettiği, yaklaşık \%3'ünün de tavsiye etmediği görülmektedir. Bu kodlara kaynaklık eden öğrenci ifadelerinden bazıları şu şekildedir: "Bence bu kitabı okumalısınız çünkü Küçük Kara Balık çok meraklı, istediği şeyleri vazgeçmeden yapıyor. Diğer balıklar onu kışkırtıyor ama Küçük Kara Balık onları dinlemiyor. Biz de kimseleri dinlemeden kendi yolumuza gitmeliyiz (Ö6)." "Kitabı okumalısınız çünkü siz bazen maceraya atılmak istersiniz ama çevreniz size izin vermez. Siz yolculuğa atılırsınız, birçok zorluğa gögüs germeye çalışırsınız. İ̧̧e bu zorlukları yenmeye çalışan küçük bir kara balığı anlatıyor. Okurken bazen üzülecek, bazen sevinecek, bazen de heyecanlanacaksını. Her yaştan çocuğun okumasını kesinlikle tavsiye ederim (Ö40)." Öğrencilerin çoğunluğu bu şekilde önerilerde bulunurken kitabı başkalarına tavsiye etmeyen öğrencilerin ifadeleri daha çok merak uyandırmaktadır. Niçin tavsiye etmediklerine ilişkin ifade edilenler şu şekilde örneklendirilebilir: "Bu kitabı okumamalılar çünkü Küçük Kara Balık gibi evinden ayrılıp sonsuz bir gezintiye çıkıp kaybolabilirler (Ö4)." "Birinci, ikinci, üçüncü sınıflara tavsiye etmem, küçük olduklarından anlayamazlar. Sadece dört, beş, altıncı sınıflara tavsiye ederim (Ö11)." Bu öğrencilerden ilki bu kitabın diğerlerine yanlış örnek olabileceğini ifade ederken ikincisi bu kitabın küçük yaş gruplarında anlaşımayacağını belirtmektedir. Öğrencilerin \%97'si kitabı başkalarına da tavsiye ederken yaklaşık \%3'ünün tavsiye etmediği tespit edilmiştir. Tavsiye eden öğrenciler, kitabı beğendiklerini okurken heyecanlandıklarını, Küçük Kara Balık'ı kendilerine örnek aldıklarını ifade etmişlerdir. Tavsiye etmeyen öğrenciler ise kitabın küçük sınıflar için uygun olmadığını ve Küçük Kara Balık'ın başına gelen olumsuz şeylerin onların da başına gelebileceğini belirtmişlerdir.

Öğrencilerin Kitaba Verdikleri Metin Merkezli ve Okur Merkezli Cevapların Dağıımına İlişkin Bulgular Öğrencilerin "Küçük Kara Balık" isimli esere verdikleri okur merkezli ve metin merkezli cevapların dağııımı Tablo 1'de gösterilmiştir.

Tablo 1.

Öğrencilerin "Küçük Kara Balık" İsimli Esere Verdikleri Okur Merkezli ve Metin Merkezli Cevapların Dağılımı

\begin{tabular}{lll}
\hline Küçük Kara Balık & $f$ & $\%$ \\
\hline Metin Merkezli Cevaplar & 119 & 41 \\
Kitabı yeniden anlatma & 1 & 0.34 \\
Kitabın içeriğini anlama & 16 & 5.47 \\
Soru sorma & - & - \\
Tahmin etme & 47 & 16.1 \\
Ana fikir & 55 & 18.8 \\
Okur Merkezli Cevaplar & 173 & 59 \\
Kişisel tepki (düşünceler ve & 58 & 19.86 \\
hisler) & & \\
Kitap ile deneyimleri arasında & 58 & 19.86 \\
bağlantılar kurma & & 19.52 \\
Kitaptaki olaylara katılma isteği & 57 &
\end{tabular}


Tablo 1'de esere yönelik yazılı tepkiler incelendiğinde, araştırmaya katılan öğrencilerin çoğunluğunun (\%59) okur-merkezli cevaplar verdiği görülmektedir. Öğrencilerin kişisel düşünceleri ve hislerini katarak (\%19.86), kitap ile kendi deneyimleri arasında bağlantılar kurdukları (\%19.86) ve kitaptaki olaylara katılma isteği göstererek tepkide bulundukları görülmektedir. Öğrencilerin estetik tepkilerini almaya yönelik sorular sorulmamasına rağmen katılımcıların büyük oranda okur merkezli tepkiler verdikleri gözlenmiştir. Tablo 1'de sunulan metin merkezli cevapların dağılımı incelendiğinde ise öğrencilerin büyük oranda ana fikir üzerine odaklandıkları (\%18.2), bunu tahmine yönelik tepkilerin izlediği (\%16.1) görülmektedir. Az sayıda, kitabın içeriğini anlamaya yönelik tepki gözlenirken (\%5.47) sadece bir tane kitabı yeniden anlatmaya yönelik cevap bulunmaktadır. Katılımcıların soru sormaya yönelik ise bir tepkide bulunmadığı görülmüştür.

\section{Tartışma, Sonuç ve Öneriler}

Edebî bir metindeki anlamın yapılandırılması ve yorumlanmasında okuyucuya düşen rolün tespit edilerek bir esere ilişkin okur tepkilerinin ortaya çıkarılmasının amaçlandığı bu araştırmada durum çalışması desenlerinden bütüncül tek durum deseni yaklaşımı benimsenmiştir. Edebî bir metindeki anlamın inşa edilmesi ve yorumlanması sürecinde okuyucuya önemli bir rol düşmesine rağmen alanda yapılan araştırmalarda çoğunlukla yazara ve yazarın ortaya koyduğu anlama, metne ve metnin yazıldığı döneme odaklanıldığı, okurun göz ardı edilerek ona edilgen bir görev yüklendiği görülmüştür. Bütün bu nedenlerden dolayı bu çalışmada okur merkeze alınarak bir çocuk edebiyatı eserini çocukların bakış açısıyla değerlendirmek hedeflenmiş, 10-11 yaş aralığındaki öğrencilerin "Küçük Kara Balık" adlı eserle ilgili okur tepkileri ortaya çıkarılmaya çalışımıştır. Öğrencilerin bu esere ilişkin okur tepkileri üç farklı şekilde analiz edilmiş ve analizlerden elde edilen sonuçlar bu doğrultuda açıklanmıştır. Birincisinde Schwartz (1992) tarafından oluşturulan değer sınıflamasına göre hazır tema ve kodlar üzerinden, ikincisinde araştırmacılar tarafından oluşturulan kod ve temalar üzerinden, üçüncüsünde Wollman-Bonilla ve Werchadlo (1995) tarafından geliştirilen, Ulusoy (2016) tarafından "ana fikir" alt teması eklenen kategoriler üzerinden değerlendirme yapılmıştır. Kitaba verilen okur tepkileri Schwartz (1992) değer sınıflamasına göre analiz edildiğinde "öz yönelim, uyarılım ve iyilikseverlik" temalarına ait olan alt değerlerin sıklık oranının yüksek olduğu, evrenselcilik ve güç temasına ait değerlerin ise öğrenci cevaplarında hiç yer almadığı tespit edilmiştir. Okur tepkilerinde en sık görülen değerler "merak duyabilmek, kendi amaçlarını seçebilmek, kararlı olmak, hayallerinden vazgeçmemek (özyönelim); cesur olmak, değişken bir hayat yaşamak, heyecanlı bir yaşantı sahibi olmak (uyarılım); yardımsever olmak, dürüst olmak, gerçek arkadaşlık (iyilikseverlik); aileye bağlılık (güvenlik); ana babaya ve yaşlılara değer vermek, itaatkâr olmak (uyma); zeki olmak, bilgili olmak (başarı); mutlu olmak (hazcılık); alçak gönüllü olmak (geleneksellik) olarak tespit edilmiştir. Belet Boyacı vd., (2017) tarafından bu esere ilişkin yapılan doküman incelemesinde bu temalardan en çok vurgulanan değerlerin kendi amaçlarını seçebilmek, özgür olmak, merak duyabilmek, açık sözlülük (özyönelim); cesur olmak (uyarılım); kibarlık (uyma) ve anlamlı bir hayat (iyilikseverlik) olduğu ifade edilmiştir. Kitabın, itaatkâr olmak (uyma), hayatın verdiklerini kabullenmek ve geleneklere bağılı olmak (geleneksellik), toplumsal düzenin sürmesini istemek (güvenlik), sosyal güç ve otorite sahibi olmak (güç) gibi değerleri desteklemediği sonucuna ulaşılmıştır. Bu da Belet Boyacı vd., (2017) tarafından yapılan doküman incelemesinde bulunamayan bazı değerlerin bu araştırmadan elde edilen okur tepkilerinde yer aldığını göstermektedir. "Güvenlik, uyma ve geleneksellik" temalarındaki alt değerlerin özellikle de "aileye değer verme ve bağlıık" değeri doküman incelemesinde bulunamazken öğrenci cevaplarında yani okur tepkilerinde yer almaktadır. Bu sonuç, aynı esere verilen farklı okur tepkilerinin somut bir göstergesidir. Araştırmacıların gözünden incelendiği zaman bu kitapta "aileye değer verme ve bağ|ıık" değeri bulunmazken okur tepkilerinde "aileye değer verme" özellikle de "anneye bağ|ılık" değerinin ön plana çıktığı görülmektedir.

Araştırmacılar tarafından oluşturulan temalar incelendiğinde öğrencilerin kitabı içselleştirdikleri ve kendi hayatları ile bağdaştırarak estetik tepkiler verdikleri görülmüş; öğrencilerin \%44'ünün kitap kahramanlarını kendi ailesine benzettiği, \%71'inin Küçük Kara Balık olmak istediği, 
\%97'sinin kitabı başkalarına tavsiye ettiği, \%54'ünün Küçük Kara Balık'a annesinin sözünü dinlemesi gerektiğini öğütlediği, \%84'ünün kitabın sonunu umutla, \%16'sının ise karamsarlıkla bitirdiği tespit edilmiştir.

Okur tepkileri, Wollman-Bonilla ve Werchadlo (1995) tarafından oluşturulan kategorilere göre analiz edildiğinde öğrencilerin \%59'unun okur-merkezli, \%41'inin metin merkezli cevaplar verdiği görülmüştür. Bu sonuçlar, öğrencilerin okuma sürecine kişisel düşüncelerini ve hislerini kattıklarını, kitap ile kendi deneyimleri arasında bağlantılar kurduklarını ve kitaptaki olaylara katılma isteği göstererek tepkide bulunduklarını göstermiştir. Katılımcıların estetik tepkilerini almaya yönelik sorular sorulmamasına rağmen öğrencilerin büyük oranda okur merkezli tepkiler verdikleri gözlenmiştir.

Bu sonuçlardan hareketle bu kitapla ilgili akla gelebilecek bazı sorular üzerinde tartışıması gerekmektedir. Örneğin "Bu kitap çocukları asiliğe, anneye karşı gelmeye yöneltmiş midir?". Bu sorunun cevabını verebilmek için okur tepkilerinden elde edilen sonuçlar şu şekilde yorumlanabilir: Okur tepkilerinde "cesur olmak, hayallerinin peşinden gitmek, yeni yerler keşfetmek, yeni arkadaşlıklar kurmak" gerektiği ancak bunları yaparken annenin rızasının alınması, onunla birlikte bu maceraların yaşanması gerektiği vurgulanmıştır. Öğrencilerden hiçbiri "ailemize ya da annemize rağmen hayallerimizin peşinden gitmeliyiz" şeklinde bir ifade kullanmamıştır. Öğrenciler Küçük Kara Balık'ın cesur olmasını, amaçlarından hedeflerinden vazgeçmemesini onaylamışlar ve kendilerine model almışlar ancak annesinin sözünü dinlememesini ve onu bırakarak keşfe çıkmasını eleştirmişlerdir. “Küçük Kara Balık'a tavsiyeniz nedir?" sorusunda öğrencilerin \%54.5’i annesinden ayrılmamasını, annesinin sözünü dinlemesini, annesini ikna etmesini, annesiyle birlikte yeni yerler görmeye gitmesini tavsiye etmişlerdir. Bunu yanı sıra \%24'ü de "Korkma, hep cesur kal..." diyerek Küçük Kara Balık'ı onayladıklarını belirten ifadeler kullanmışlardır. Çıkan bu sonuçlar bize kitaplardan korkup yasaklatmak, çocukların okumasını sakıncalı görmekten öte onlara okurken rehber olmamız gerektiğini göstermektedir. Okur merkezli tepkilerin estetik tepkiler olduğu, iyi bir okur olmanın adımlarının da estetik okumalar sayesinde atıldığı gerçeği göz önünde tutularak çocuk edebiyatı eserleri ile yürütülen etkileşimli okuma çalışmalarında estetik okuma temel alınmalı, çocukların okunan materyalden keyif alması sağlanmalıdır. Özellikle de öyküleyici metinler okuma anlama çalışmaları adına sürekli soru cevap yöntemiyle boğulmamalı, metnin içselleştirilerek öğrencilerin kendi yaşamlarıyla bağlantı kuracak yönlerine odaklanılmalıdır. Metindeki anlamın yapılandırılmasında öğrencinin aktif rol üstlenmesi sağlanmalıdır.

Çalışmanın sonuçları öğrencilerin Küçük Kara Balık adlı masalı kendi yaşamları ile ilişkilendirerek kitaptaki kahramanlar ile kendi hayatlarındaki kişileri bağdaştırdıklarını göstermiştir. Bu da Rosenblatt (1978)'ın okur tepki teorisine göre okur merkezli ve estetik okuma deneyimi yaşadıklarını ortaya koymaktadır. Many ve Wiseman (1992) tarafından yapılan çalışmada üçüncü sınıf öğrencileri ile yürütülen etkileşimli okuma çalışmaları sonrasında da öğrencilerin bu çalışmanın sonuçlarına benzer şekilde okur merkezli tepkiler verdiği, okumayı estetik bir deneyim olarak ele alan yanıtlar yazdıkları görülmüştür. Lee (2013) tarafından yapılan bir başka araştırmada da okur tepkileri alınarak yürütülen okuma çalışmalarının öğrenci deneyimlerini ortaya çıkararak metnin daha iyi anlaşımasında etkili olduğu ve estetik okuma deneyiminin öğrencilerin okuma motivasyonlarını artırdığı sonucuna ulaşılmıştır. Yılmaz (2013)'ın çalışmasında okur tepki teorisi doğrultusunda yürütülen okuma çalışmalarının öğrencilerin fikirlerini özgürce ifade etmelerine yardımcı olduğu ifade edilmiştir. Ulusoy (2016) tarafından yürütülen araştırmada ikinci sınıf öğrencilerinin resimli çocuk kitaplarına yönelik okur tepkileri alınmış, öğrencilerin okur-merkezli cevaplar vererek kitaplarla kendi deneyimleri arasında bağlantı kurabildikleri görülmüştür. Yekeler ve Ulusoy (2017)'un çalışmasında öğrencilerin bilgilendirici çocuk kitaplarına yönelik tepkileri incelenmiş, kitaplara yönelik öğrenci tepkilerinin daha çok okur merkezli olduğu sonucuna ulaşıımıştır. Çevik ve Müldür (2019)'ün bir çocuk kitabına ilişkin okur tepkilerini ortaya çıkarmaya çalıştıkları araştırmalarında da beşinci sınıf öğrencilerinin okudukları kitapla kişisel bağ kurdukları ve kendi hayatlarıyla özdeşleşen olaylara tepki göstererek okur-merkezli tepkiler verdikleri tespit edilmiştir. Bu çalışmadan elde edilen sonuçlar ile sözü geçen araştırmaların sonuçları, öğrencilerin kitaplara yönelik okur merkezli tepki vermiş olmaları açısından paralellik göstermektedir. 
Samed Behrengi'nin hikâyelerindeki eğitsel iletiler üzerine Akçay ve Baş (2015) tarafından yürütülen araştırmada, bu yazarın eserlerinde eğitsel iletilerin yer aldığı ve bunlar içinde kişisel gelişimi destekleyen iletilerin ön plana çıktığı belirtilmiş; "Küçük Kara Balık" adlı eserde kişisel gelişimi destekleyen on üç, toplumsal gelişimi destekleyen bir ileti olduğu tespit edilmiştir. Bu kitaba ilişkin okur tepkilerinde de kişisel gelişimi destekleyen değerlerin ön plana çıktığı görülmüş, evrenselcilik ve güç temasına ait değerlerin okur tepkilerinde hiç yer almadığı tespit edilmiştir. Okur tepkilerinden elde edilen tüm bu sonuçların değerlendirilebilmesi için çalışma grubundaki öğrencilerin ahlaki gelişim dönemlerinin açıklanması ihtiyacı doğmaktadır. Piaget, ahlaki gelişim dönemini dışa bağımlı ve özerk dönem olarak iki evrede inceler. İlk evre çocuğun aileye ve var olan kurallara bağlı olduğu, kendini bağımlı hissettiği bir dönem iken ikinci evre artık ergenliğe de geçişle birlikte bağımsızlaşma ve var olan kuralları sorgulama, gerektiğinde bu kuralların değiştirebileceğini kavrama dönemidir. Bu araştırmanın çalışma grubunu oluşturan beşinci sınıf öğrencileri son çocukluk döneminden ergenliğe geçiş aşamasındadır. Erikson'un psikososyal gelişim dönemlerine göre 12-18 yaş ergenlik dönemi olarak kabul edilir (Can, 2017). Çocuk büyüdükçe gelenek ve kurallara uygun davranma eğilimi kademeli bir şekilde kaybolur. Çocuk yaşça büyürken devamlı olarak özgürleştiği için baskının yerini iş birliği, uymanın yerini de özerklik alır (Aypay, 2018). Özerk dönem olarak adlandırılan ikinci dönemin başlangıcından itibaren, 11. yaşla birlikte çocuklar, "kendi dışlarında oluşturulmuş olan kuralların değiştirilemez olmadığını, istenirse anlaşarak kuralları değiştirebileceklerini fark etmeye başlarlar. Ayrıca ihlal edilen bir kuralla ilgili bir ahlaki yargıda, kuralın ihlal edilmiş olmasından öte bu davranışı haklı kılacak bir nedenin olup olmaması belirleyici olur." (Can, 2017, s. 142). Beşinci sınıf düzeyindeki öğrencilerin Küçük Kara Balık'ın hayallerinin peşinden gitmesini onaylaması kuralların ihlal edilmesinde haklı bir neden bulduklarını göstermektedir. Öğrencilerin bir kısmının aileden bağımsızlaştığı, çoğunluğunun ise hâlâ anne ve aileye bağlılığını sürdürdüğü görülmektedir. Bu bulgular dışa bağımlı dönemden özerk döneme geçiş süreci olan 10-11 yaş aralı̆ının bir özelliği olarak değerlendirilebilir. Bu bakış açısından hareketle okur tepkilerinde "evrensel" değerlere ulaşılamamasının sebebi olarak da öğrencilerin ahlaki gelişim evresinin etkili olduğu düşünülmektedir. Kohlberg'in ahlak gelişim evreleri incelendiğinde bu öğrenci grubunun gelenek öncesinden geleneksel düzeye yani II. düzeye geçtiği görülmektedir. Bu düzey 10-20 yaşlarını kapsamaktadır, "evrensel ilkeler ve sosyal sözleşme" ise gelenek ötesi evrede yer almaktadır.

Bu çalışmada 10-11 yaş düzeyindeki çocuklar ile çalışıldığı için alınan tepkiler bu yaş grubunun tepkilerine örnek teşkil etmektedir. Okur tepkisinin farklı yaş düzeylerinde değişip değişmediğini görebilmek adına başka yaş gruplarından alınan örneklemler üzerinde çalışılması gerekmektedir. Ortaokul sekizinci sınıf düzeyinde ya da orta öğretim düzeyinde öğrenim gören öğrencilerin aynı kitaba nasıl tepki verdikleri yapılacak çalışmalar ile ortaya çıkarılabilir. Metnin ötesinde okurun varlığını ve tepkisini görebilmek adına bu çalışmaların yapılması ve farklı yaş düzeylerinin karşılaştırııması önem arz etmektedir. Bu çalışmada, bir edebî eseri öğrencilerin gözünden tanımak ve onların kitaptaki çıkarımlarını görmek amaçlandığı için öğrencilere yöneltilen sorular okur-tepki soruları ile; katılımcı grubu 10-11 yaş aralı̆ı ile sınırlı tutulmuştur. Başka çalışmalarda hem metin merkezli hem de okur merkezli sorulara yer verilerek öğrencilerin her iki soru türüne verdiği cevaplar analiz edilebilir. Bu şekilde cevaplardaki ağrılık oranının hangi soru tipinde yoğunlaştığı görülebilir. Aynı zamanda farklı yaş grupları ile çalışılarak ahlaki ve bilişsel gelişim dönemlerinin okur tepkileri üzerindeki etkileri karşılaştırılabilir.

\section{Kaynaklar}

Akçay, S. ve Baş, B. (2015). Samed Behrengi'nin hikâyelerindeki eğitsel iletiler üzerine bir araştırma. Ana Dili Eğitimi Dergisi, 3(3), 77-90.

Akkaya, N. (2014). Keloğlan masallarında yer alan değerlerin incelenmesi. Akademik Sosyal Araştırmalar Dergisi, 2(1), 312-324.

Aktaş, N. ve Ateş, S. (2017). Ödüllü resimli çocuk kitaplarındaki duygu durumlarının ve okuyuculara yansımalarının incelenmesi. 1. Uluslararası Sınırsız Eğitim ve Araştırma Sempozyumu, 24-26 Nisan, Antalya (Sözlü Bildiri). 
Alamdar, S.G. (2017). Samed Behrengi'nin Küçük Kara Balık adlı kitabının özerk benlikli çocuk ve genç yetiştirme sürecindeki önemi. International Journal of Language Academy, 5(4), 189-204.

Anderson, R., \& Pearson, D. (1984). A schema-theoretic view of basic processes in reading. In P.D. Pearson, R. Barr, M.L. Kamil, \& P. Mosenthal (Eds.), Handbook of reading research (Vol. 1, pp. 255-291). New York: Longman.

Arıcı, A. F. (2016). Estetik değer oluşturmada masalların rolü: Türk masalları örneği. Erzincan Üniversitesi Eğitim Fakültesi Dergisi, 18(2), 1017-1035.

Arseven, T. (2005). Mesaj açısından çocuk kitapları. Hece Çocuk Edebiyatı Özel Sayısı, 104- 105.

Ateş, S. (2011). Illköğretim beşinci sınıf Türkçe dersi öğrenme-öğretme sürecinin anlama öğretimi açısından değerlendirilmesi. Yayımlanmamış doktora tezi, Gazi Üniversitesi Eğitim Bilimleri Enstitüsü, Ankara.

Ateş, S., Döğmeci, Y., Güray, E. ve Gürsoy, F.F. (2016). Sınıf içi konuşmaların bir analizi: Diyalojik mi monolojik mi? Ahi Evran Üniversitesi Kırşehir Eğitim Fakültesi Dergisi, 17, 603-625.

Ateş, S., Yıldırım, K. ve Çetinkaya, F.Ç. (2019). Çocuk kitaplarını çözümlemeye yönelik bir uygulama: Samed Behrengi ve Küçük Kara Balık örneği. Turkish Studies Language and Literature, 14(3), 1023-1049.

Aypay, A. (2018). Ahlak (törel) gelişimi. Engin Deniz (Ed.), Eğitim Psikolojisi içinde (s. 165-195). Ankara: Pegem Akademi.

Baktır, H. (2018). Metinde anlam: Okur - tepkisi eleştiri kuramı. Temaşa Erciyes Üniversitesi Felsefe Bölümü Dergisi, 8, 97-105.

Belet Boyacı, Ş. D., Güner, M. ve Babadağ, G. (2017). “Dünyada başka şekilde yaşamak da mümkün mü?” Değer eğitiminde "Küçük Kara Balık” örneği. Eğitimde Nitel Araştırmalar Dergisi, 5(3), 172-194.

Bogdan, R. C., \& Biklen, S. K. (2003). Qualitative research for education: An introduction to theories and methods. New York: Pearson Education Group.

Bransford, J., Brown, A., \& Cocking, R. (Eds.). (1999). How people learn: Brain, mind, experience, and school. Washington, DC: National Academy Press.

Campbell, J. B. (2011). Take it out of class: Exploring virtual literature circles. Journal of Adolescent \& Adult Literacy, 54(8), 557-567.

Can, G. (2017). Kişilik gelişimi (Psikososyal ve ahlak gelişimi). Binnur Yeşilyaprak (Ed.). Eğitim Psikolojisi içinde (s. 123-163). Ankara: Pegem Akademi.

Clarke, L. W., \& Holwadel, J. (2007). Help! What is wrong with these literature circles and how can we fix them?. The Reading Teacher, 61(1), 20-29.

Cox, C., \& Many, J. E. (1992). Stance towards a literary work: Applying the transactional theory to children's responses. Reading Psychology: An International Quarterly, 13(1), 37-72.

Creswell, J.W. (2017). Nitel araştırmacılar için 30 temel beceri, Hasan Özcan (Çev.). Ankara: Anı.

Creswell, J.W. (2018). Beş nitel araştırma yaklaşımı. Nitel araştırma yöntemleri. Mesut Bütün ve Selçuk Beşir Demir (Çev. Ed.). Beş yaklaşıma göre nitel araştırma ve araştırma deseni içinde (s. 69110). Ankara: Siyasal.

Çevik, A., \& Müldür, M. (2019). "Vapurları Seven Çocuk" adlı kitabın okur-tepki teorisi ile değerlendirilmesi. International Journal of Languages' Education and Teaching, 7(3), 40-50.

Çolaker, Ö. (2009). Samed Behrengi'nin "Küçük Kara Balık", Rıchard Bach'ın "Martı Jonathan Lıvıngston" ve Cahit Zarifoğlu'nun "Motorlu Kuş" adlı öykülerindeki ana karakterlerin kişilik gelişimi, bireyselleşme ve toplumsallaşma açısından karşılaştırılması. Yayımlanmamış Yüksek Lisans Tezi, Osmangazi Üniversitesi, Eskişehir.

Erdal, K. (2009). Eğitim değerleri açısından çocuk kitapları. Akademik Bakış Uluslararası Hakemli Sosyal Bilimler E-Dergisi, 17, 1-18.

Erkan, G. ve Aykaç, M. (2014). Samed Behrengi'nin kitaplarıyla kurgulanan yaratıcı drama etkinliklerinin öğrencilerin yazma becerisi ve tutumlarına etkisi. Uluslararası Sosyal Araştırmalar Dergisi, $7(31), 600-610$.

Ertan, G. G. (2011). Samed-i Behrengî'nin hikâyeciliği ve İran çocuk edebiyatındaki yeri. Selçuk Üniversitesi Sosyal Bilimler Enstitüsü Dergisi, 26, 164-171. 
Gözütok, T. K. (2008). Güney Azerbaycanlı yazar Samed Behrengi'nin hikâye ve masal dünyası. Modern Türklük Araştırmaları Dergisi, 5(2), 31-51.

Hancock, M. R. (2008). A celebration of literature and response: Children, books, and teachers in K-8 classrooms (3rd ed.). Columbus, Ohio: Pearson-Merrill Prentice Hall.

Kaya Tosun, D. (2018). Okuma çemberlerinin okuduğunu anlama, akıcı okuma, okuma motivasyonu ve sosyal beceriler üzerindeki etkisi ve okur tepkilerinin belirlenmesi. Yayımlanmamış Doktora Tezi, Pamukkale Üniversitesi Eğitim Bilimleri Enstitüsü, Denizli.

Karagöz, B. (2018). Ortaokul 5. sınıf öğrencilerinin resimli çocuk kitaplarına ilişkin tepkileri üzerine bir inceleme. Ana Dili Eğitimi Dergisi, 6(4), 1198-1218.

Karatay, H. (Eylül, 2007). Değer aktarımı açısından yerli ve yabancı çocuk edebiyatı ürünleri. 38. ICANAS, Uluslararası Asya ve Kuzey Afrika Çalışmaları Kongresi, Ankara.

Körükçü, Ö., Acun Kapkıran, N. ve Aral, N. (2016). Schwartz'ın modeline göre 3-6 yaş resimli çocuk kitaplarında değerlerin incelenmesi. Mehmet Akif Ersoy Üniversitesi Eğitim Fakültesi Dergisi, 38, 133-151.

Lee, H., C. (2013). An examination of ESL Taiwanese university students' multimodal reading responses. Literacy Research and Instruction, 52(3), 192-203.

Lüleci, M. (2014). Edebîlik ve edebî metinlerde okuma sürecinin üç bileşeni. Gazi Turkiyat Türkoloji Araştırmaları Dergisi, 15, 177-192.

Maltepe, S. (2009). Türkçe öğretmeni adaylarının çocuk edebiyatı ürünlerini seçebilme yeterlilikleri. Balıkesir Üniversitesi Sosyal Bilimler Enstitüsü Dergisi, 12(21), 398-412.

Many, J. E., \& Wiseman, D. L. (1992). The effect of teaching approach on third-grade students' response to literature. Journal of Reading Behavior, 24(3), 265-287.

Merriam, S. B. (2013). Nitel araştırma: Desen ve uygulama için bir rehber (3. Basım). Ankara: Nobel.

Moreillon, J. (2007). Collaborative strategies for teaching reading comprehension: Maximizing your impact. Chicago: ALA.

Patton, M.Q. (2002). Qualitative research and evaluation methods. Thousand Oaks, CA: Sage Publications.

Rosenblatt, L. M. (1978). The reader, the text, the poem: The transactional theory of literary work. Carbondale: Southern Illinois University Press.

Rosenblatt, L. M. (2004). The transactional theory of reading and writing. Theoretical Models and Processess of Reading, 5th edition, Robert B. Ruddell, \& Norman J. Unrau, editors, International Reading Association, article 48, 1363-1398.

Rosenblatt, L.M. (1983). Literature as exploration (4th ed.). New York: Modern Language Association.

Schwartz, S. H. (1992). Universals in the content and structure of values: Theory and empirical tests in 20 countries. Erişim adresi: http://citeseerx.ist.psu.edu/viewdoc/download?doi=10.1.1.220.3674\&rep=rep1\&type=pdf

Tutty, L.M., Rothery, M.A., \& Grinnell, R.M. (1996). Qualitative research for social workers. Boston: Allyn and Bacon.

Ulusoy, M. (2016). Resimli çocuk kitapları ve okur-tepki teorisi. Illköğretim Online, 15(2), 487-497.

Uzuner Yurt, S. ve Şimşek, T. (2016). Sevim Ak'ın öykülerinin eğitsel değerleri. Ana Dili Eğitimi Dergisi, $4(4), 474-488$.

Wolf, S. A. (2004). Interpreting literature with children. New Jersey London: Lawrence Erlbaum Associates.

Wollman-Bonilla, J. E., \& Werchadlo, B. (1995). Literature response journals in a first-grade classroom. Language Arts, 72(8), 562-570.

Yekeler, A. D. ve Ulusoy, M. (2017). İlkokul öğrencilerinin bilgi verici resimli çocuk kitaplarına yönelik tepkileri. Anadolu Kültürel Araştırmalar Dergisi, 1(2), 20-39.

Yıldıım, A. ve Şimşek, H. (2016). Sosyal bilimlerde nitel araştırma yöntemleri. Ankara: Seçkin.

Yılmaz, C. (2013). Literature instruction through reader-response approach: Does it foster reading comprehension?. International Journal of Language Learning and Applied Linguistics World, $3(4), 50-58$. 
Yuran, S., Ateş, S. ve Çetinkaya, F. Ç. (2017). Resimli çocuk kitapları, dijital hikâyeler ve okur tepkileri. 1. Uluslararası Sınırsız Eğitim ve Araştırma Sempozyumu, 24-26 Nisan, Antalya (Sözlü Bildiri).

\section{Introduction}

\section{Extended Abstract}

In the present study, it was aimed to evaluate a children's literature work from the viewpoint of children in a reader-centered manner and reveal the reader responses of students between the ages of 10-11 on the work titled The Little Black Fish. In the selection of the children's literature work to be used in the study, the related literature was reviewed and the work titled The Little Black Fish, which many studies stated to be suitable for use in values education (Akçay ve Baş, 2015; Alamdar, 2017; Ateş, Yıldırım ve Çetinkaya, 2019; Belet Boyacı, Güner ve Babadağ, 2017; Çolaker, 2009; Ertan, 2011; Gözütok, 2008) was selected. Another factor that affected the selection of the said book was that certain adults, who are considered to be decision-makers in terms of a book's suitability for children, had the opinion that this work was not suitable for children (Ateş et al., 2019). This is because the reaction of children to a book that is approached negatively by adults is a subject of interest.

\section{Method}

In the present study, the qualitative case study design and the holistic single case study design were used. Case study is the process of making in-depth descriptions and analyses of a limited system (case) (Merriam, 2013), gathering detailed and in-depth information from one or multiple limited systems through multiple information sources and reporting the themes discovered (Creswell, 2018).

\section{Result and Discussion}

Reader responses to the book were analyzed in three different ways; the first one was based on ready-made themes and codes according to the value classification created by Schwartz (1992) and the second one was based on the codes and themes created by the researchers, the third was based on the categories developed by Wollman-Bonilla and Werchadlo (1995). When the reader responses to the book were analyzed according to Schwartz's (1992) value classification, it was found that the frequency of the subtheme belonging to the themes of "self-direction, stimulation and benevolence" was high, and the values belonging to universalism and to the theme of power were not included in student responses at all. When the themes created based on the data of this study were examined, it was discovered that the students internalized the book and gave aesthetic responses while associating the book with their personal lives, and the value "family valuation", especially "commitment to the mother" was found to be at the forefront. Beyond the text, in order to see the existence and response of the reader, it is recommended to work with different age groups in order to find out the effects of moral and cognitive developmental stages on reader responses.

The results of the present study have shown that the students related the work titled The Little Black Fish to their own lives and formed connections between the characters in the book and people in their lives. This finding reveals that the students experienced a reader-centered and aesthetical reading experience according to the Reader Response theory by Rosenblatt (1978). Similar to the results of the present study, in the interactive reading activities carried out with third-grade students as part of the study conducted by Many and Wiseman (1992), it was observed that students gave reader-centered responses and gave responses with a perspective of reading as an aesthetical experience. In another study conducted by Lee (2013), it was concluded that reading activities carried out by obtaining reader responses were effective in establishing better comprehension of the text by revealing student experiences and that the aesthetic reading experience increased the reading motivations of students. In the study conducted by Yılmaz (2013), it was stated that reading activities carried out in accordance with the Reader Response theory helped students to express their opinions freely. In the study conducted by Ulusoy (2016), the reader responses of second-grade students on illustrated children's books were obtained and it was observed that students were able to form a connection between the books and their own experiences by giving reader-centered responses. Yekeler and Ulusoy (2017) examined the responses of students on educational children's books and 
concluded that students responses on the books were mainly reader-centered. In the study conducted by Çevik and Müldür (2019) with the aim of revealing the reader responses towards a children's book, it was determined that fifth-grade students formed personal bonds with the books they read and gave reader-centered responses by reacting to the events that corresponded to their lives. The results of the aforementioned studies and the present study are in parallel with each other in terms of the fact that the students gave reader-centered responses towards the books. 